\title{
EFFECTS OF GROUND ON EARTHQUAKE MOTION
}

\author{
By B. Gutenberg
}

\begin{abstract}
Earthquake damage at a given location depends on properties of the arriving elastic waves, of the ground at the shaken site, and of the structures involved. To investigate effects of the ground on the motion at the surface, five identical seismographs have been operated temporarily at 25 locations within 30 miles from the Seismological Laboratory of the California Institute of Technology, Pasadena, and their records have been compared with those written by an identical instrument recording in routine at the Seismological Laboratory. The ratio of amplitudes at sites on fairly dry alluvium more than 500 feet deep to those at the Seismological Laboratory (on crystalline rock) is frequently $5: 1$ or more for earthquake waves having periods of 1 to $11 / 2$ sec. For waves having periods of $0.1 \pm$ sec. and waves having periods exceeding 10 sec. (length more than 10 miles) the corresponding differences in amplitudes are small. Amplitudes of earthquake waves and of the continuous unrest of the ground recorded at sites on water-saturated soft ground may be ten times those recorded at the Laboratory. The period of waves for which the response relative to that at the Seismological Laboratory is greatest usually decreases as the thickness of the alluvium decreases and is about $1 / 4$ sec. at stations on alluvium $100 \pm$ feet thick. At stations on crystalline rock the motion of the ground does not differ significantly from that at the Laboratory for waves having periods exceeding $1 / 4$ sec.

At sites on alluvium, relatively strong shaking lasts several times as long as at those on crystalline rock; usually this ratio decreases with decreasing thickness of the alluvium. Ground effects may produce appreciable differences in duration and amount of shaking even at localities only a fraction of a mile apart. The importance of selecting crystalline rock or at least dry ground and avoiding water-saturated soft ground for foundations of buildings to reduce potential earthquake damage is stressed.
\end{abstract}

\section{INTRODUCTION}

DAMAGE from shaking of all kinds is appreciably affected by properties of the ground. While Mallet (1862, Vol. 2, p. 359) after investigating the Neapolitan earthquake of 1857 considered the effect of ground to be secondary, Milne (1908, p. 103) concluded from artificial explosions recorded during 1881-1885 that in soft, damp ground it is easy to produce vibrations of large amplitude and considerable duration while in soft rock it is difficult to produce a disturbance great enough to be recorded by the comparatively crude instruments of that day. He also pointed out $(1908$, p. 147) that marshy, wet ground is "a bad foundation" in earthquakes. Sieberg (1904, p. 113) stated that structures on loose soil (gravel, clay) are relatively more damaged during earthquakes than those on solid rock, and asserted that thin layers of loose material deposited on rock act like a resonator. Reid (1910, p. 55) used observed intensities of the California earthquake of 1906 to find "foundation coefficients" relative to solid rocks (1.0), e.g., 1.6 for sandstone, 2.4 and 4.4 for sand, and up to 12 on made land and marsh. Neumann $(1954$, fig. 2) has correlated earthquake intensity on sediments with that on granitic rock. Kanai, Takahashi, and Kawasumi (1956) have summarized research on effects of ground on earthquake damage in Japan. Additional papers on related subjects may be found in the Bulletin of the Earthquake Research Institute in Tokyo.

Whereas the foregoing results are based mainly on earthquake effects, Gutenberg

Manuscript received for publication April 11, 1957. 
used records of microseisms to determine relative amplitudes for stations on different ground. On the basis of these and other data, Gutenberg (1927, p. 60) found the following amplitude factors, taking amplitudes on rock as unit: sandstone, up to 3 ; dry sand, about $3 \frac{1}{2}$; marshy land, 12 . Calculations of earthquake magnitudes required establishing of "station corrections"; however, in addition to effects of ground, these include factors resulting from instrumental properties.

To establish the average ratio of earthquake amplitudes recorded on the campus of the California Institute of Technology to those recorded at the Seismological Laboratory, Gutenberg and Richter (1956) operated a standard torsion N-S seismograph (instrument $A$ of the following investigation) from February 1 to March 15,1955 , in the basement of the Athenaeum on the campus (CIT, on about 900 feet of alluvium) and compared the records with those written simultaneously by the identical routine instrument (I) at the Seismological Laboratory (SL, on crystalline rock). The ratio of the average maxima of waves having periods of the order of 1 sec. in near-by earthquakes at CIT to those at SL, they found to be about $4: 1$. After detailed comparison, Gutenberg (1956a) concluded that the first wave of a new phase usually records with rather small differences at the two sites, but that later waves having periods $T \leqq 2$ sec. record with appreciably larger amplitudes at CIT than at SL. Moreover, relatively large amplitudes continue longer at CIT than at SL.

A similar comparison (Gutenberg, 1956b) of seismograms written on Mount Wilson (MtW, on crystalline rock) with the corresponding records written at SL. shows that usually the first $\mathrm{P}$ and $\mathrm{S}$ waves of near-by shocks recorded slightly larger at $\mathrm{SL}$ than at $\mathrm{MtW}$, later waves slightly larger at $\mathrm{MtW}$. Duration of relatively large motion was frequently a few seconds longer on $\mathrm{MtW}$ than at SL. While the wave periods at CIT are usually about the same as those at SL, the periods recorded simultaneously on $\mathrm{MtW}$ are frequently slightly shorter. Comparisons of seismograms written by instruments of the Ishimoto tromometer type (magnification of 200) in the Kawasaki and Turumi (Japan) areas (Omote, Komaki, and Kobayashi, 1956) indicate significant differences, depending on the thickness of the alluvium.

The relatively great differences in amplitudes found for a given near-by shock at sites on different types of ground made it advisable to compare records written simultaneously at several sites, and to select locations with widely different structural properties for successive investigation.

\section{Periods of Waves in Near-by Earthquakes}

A statistical investigation of wave periods prevailing in records of near-by earthquakes in southern California has been made by Gutenberg (1936). Figure 1 shows the frequency of periods recorded at the Pasadena Seismological Laboratory (SL) in the S group (which usually contains the largest displacements), separately for short- and for long-period instruments, for three ranges of epicentral distances. At epicentral distances of 100 to $200 \mathrm{~km}$. the maximum frequency indicated by longperiod instruments is about 0.1 sec. greater than that found from short-period instruments; at smaller distances there is no noticeable difference. Thus, records of 


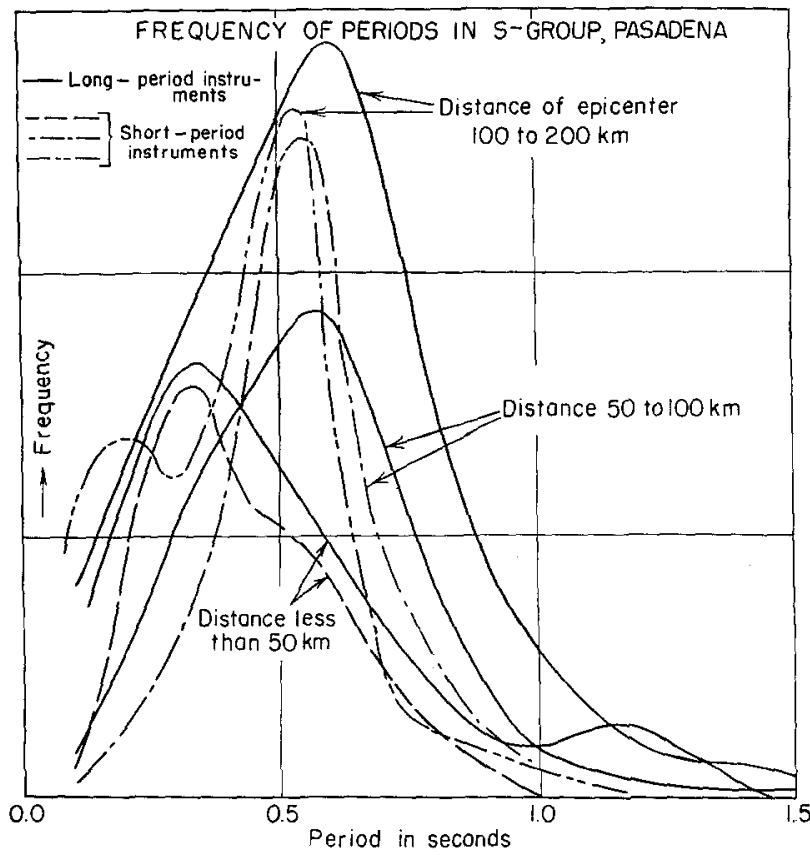

Fig. 1. Relative frequency of periods in $\mathbf{S}$ group of near-by earthquakes recorded at Pasadena; based on Gutenberg (1936). Long-period instruments include torsion seismographs with period of 6 sec. and long-period Benioff seismographs; short-period instruments include standard torsion and short-period Benioff seismographs.

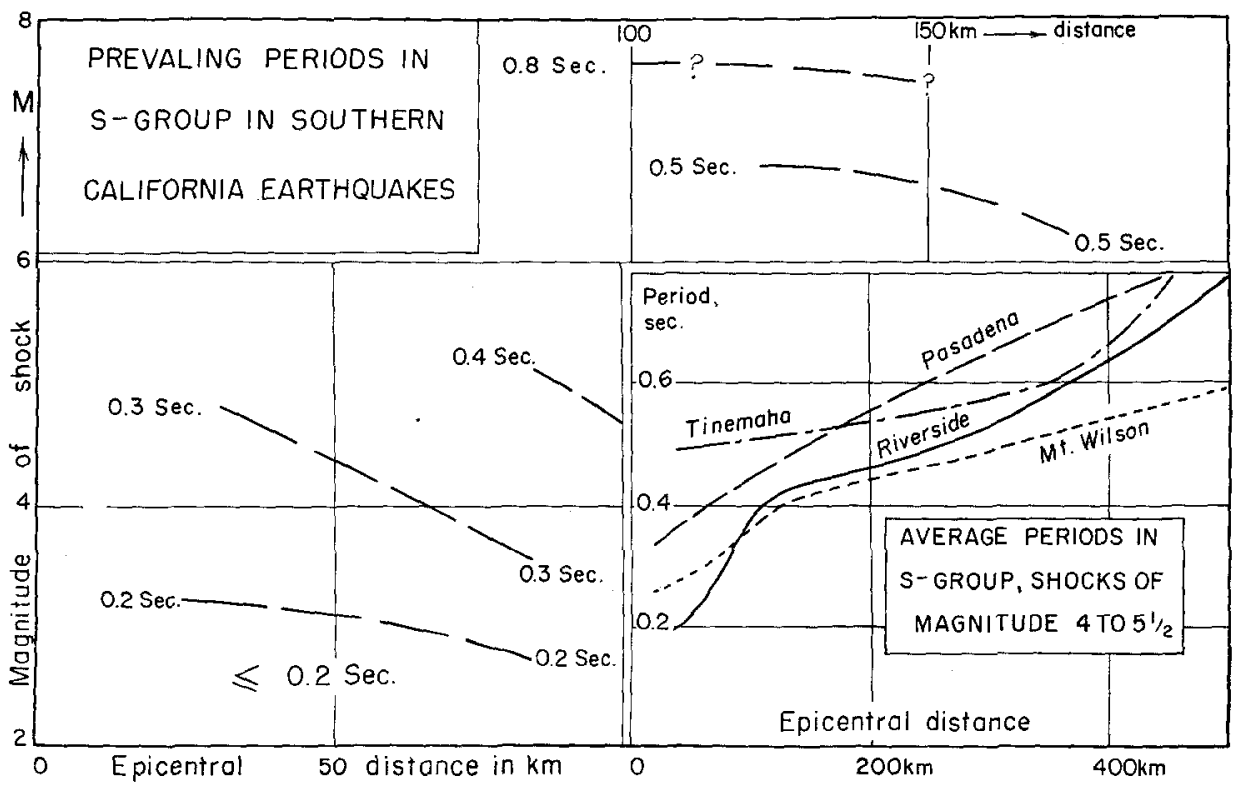

Fig, 2. Prevailing periods in S group of near-by shocks recorded in southern California as function of epicentral distance and of earthquake magnitude $M$; based on Gutenberg (1936) and readings published by the U. S. Coast and Geodetic Survey. Inset: Average periods in S group as function of epicentral distance at four stations; based on Gutenberg (1936). 
standard torsion seismographs do not appreciably distort the relative importance of periods of ground motion in near-by shocks.

Figure 2 (inset) shows periods prevailing at selected stations. The differences are significant. This has also been found by Omote, Komaki, and Kobayashi (1956) for nine stations near Tokyo. The main part of figure 2 indicates that in shocks causing light damage wave periods of $1 / 4$ to $1 / 2$ sec. can be expected for the largest waves in the epicentral region, while in the maximum portion of major shocks in southern California waves with periods near 1 sec. prevail. Omote, Komaki, and Kobayashi (1956, pp. 361, 362) find that with increasing wave amplitudes the periods approach asymptotically a given value, depending on the thickness of the alluvium. In the region investigated by them it is about $0.9 \mathrm{sec}$.

\section{INSTRUMENTS USED}

Standard torsion seismographs (Anderson-Wood, 1925) are well suited for the present purpose. Mr. F. Lehner had a wooden base made for each set with marked places for seismograph, lens, drum, minute marker (Sangamo Electric Company Contactor Units BC-608-A), etc.; radio time signals were not recorded at sites near SL. With some experience it takes two men about one hour to have a set installed and in operation.

All instruments have a free period of 0.8 sec., static magnification of 2,800 , and damping about $50: 1$. The distance from the mirror to the drum was $100 \mathrm{~cm}$. except that it was only $90 \mathrm{~cm}$. for instrument A during $1956-57$; consequently, all trace amplitudes obtained from A during 1956-57 have been multiplied by 1.11. All instruments recorded at least at the beginning (example in figure 3 ) and end of the experiments at SL for comparison of their records with those of instrument II at SL, and at each new installation tilt sensitivity tests have been made. At CIT as well as at NM two different instruments recorded during different periods without indication of noticeable difference in the general results. A comparison of records written simultaneously at six locations at SL will be discussed later (fig. 23).

Mr. F. Lehner has tested two instruments on a small shaking table of his own construction. The observed and calculated magnification $\mathrm{V}$ for continuous sinusoidal waves having periods $T$ of 0.2 to 10 seconds agree within the limits of accuracy needed for the present research (fig. 4 ). For $T \leqq 0.1$ sec. the actual magnification shows appreciable erratic deviations from the theory; but such waves are rarely recorded by torsion seismographs; they should not be used in studies based on amplitudes. Earthquake records written by instruments constructed for geophysical prospecting (see, e.g., Sklar, 1955, p. 121) show that earthquake waves with periods of appreciably less than 0.1 sec. exist in the epicentral region.

If the period $T$ of the waves increases from 0.1 to 0.5 sec., the response of the instruments decreases only slightly (fig. 4), but with $T$ increasing beyond 1 sec., $V$ decreases rapidly. Consequently, waves having periods of less than 1 sec. are overemphasized in the seismograms relative to longer waves. This does not affect appreciably ratios of amplitudes recorded at different stations if the waves have nearly the same period.

A combination of all data indicates that waves recorded by torsion seismographs 
1956 Nov. 3,2314 P.S.T. 10 sec.
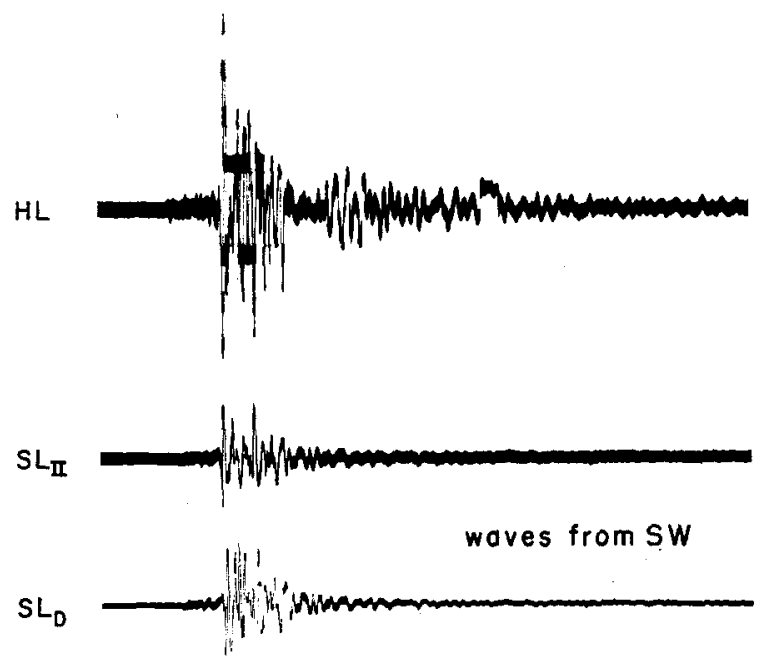

Fig. 3. Earthquake of November 3, 1956, magnitude $2 \frac{1}{4} \pm$, recorded by instrument $B$ at $H L$ (epicentral distance $\Delta$ about $21 \mathrm{~km}$.), routine instrument II, and instrument $\mathrm{D}$, both at SL $(\Delta$ about $17 \mathrm{~km}$.).

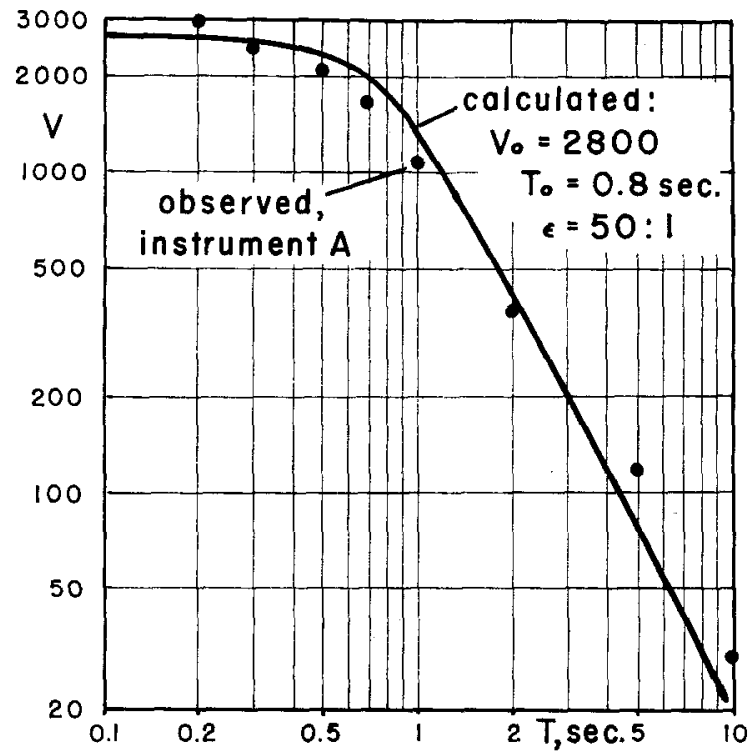

Fig. 4. Magnification $\mathrm{V}$ of instrument $\mathrm{A}$ for continuous sinusoidal waves of period $T$ observed by Mr. F. Lehner on shaking table, and calculated curve. 
carefully installed on the same city lot on a concrete slab at or below the ground floor should rarely show differences in amplitudes amounting to a ratio as high as $11 / 2: 1$, regardless of whether the installation is in a frame or reinforced concrete structure, large or small, house or garage.

\section{The Stations}

From October, 1956, to April, 1957, the instruments A to E recorded the E-W component of the ground motion on concrete floors at or below ground level. Except for CCS (Compton) and HPC (Huntington Park) a displacement upward on the record corresponds to a movement of the ground towards the east.

In the description of the sites, an asterisk after the symbol of a station indicates the home of one of the staff members or assistants of the Seismological Laboratory who has changed the records. Most data on the thickness of the alluvium under the sites are uncertain; data on the thickness of older sediments give usually only the order of magnitude, and some are based on far extrapolation.

Locations of the sites are shown in figures 5 and 6 . In figure 5 the probable order of magnitude of the thickness of the alluvium is indicated, based mainly on $\mathrm{Bu}$ walda (1948), Eckis (1934), and oral information supplied by J. P. Buwalda in the course of discussions in the area between 1930 and 1940. These sources have also been used to draft figures 7 to 9, for which, in addition, data in Jahns (1954), Uhrig and Schafer (1937), and the original material of Gutenberg and Buwalda (1935) have been used. Figures 7 to 9 are only sketches to show probable structural conditions at the various sites in connection with the seismograms obtained there; they are not based on any detailed special investigation of the author. Data of Eckis (1934) on ground-water tables have been supplemented by recent findings of the California State Division of Water Resources and by the Pasadena Water Department.

The following is a list of the sites in alphabetic order of the abbreviations used throughout the paper:

CCS. Compton City School warehouse, 406 South Tamarind, Compton; near Alameda Street and about $200 \mathrm{~m}$. north of Olive Street, $28 \mathrm{~km}$. (171/2 miles) south of SL. Roughly 2,000 feet $(600 \pm \mathrm{m}$.) of alluvium over roughly 2 miles $(31 / 2 \mathrm{~km}$.) of Tertiary sediments and possibly several km. of Franciscan (Jurassic?) schist. Ground-water level roughly 100 feet below surface. Instrument E on floor of onestory metal sheet warehouse, February 14 to March 15, 1957.

CFR*. Residence of Dr. C. F. Richter, 1820 Kenneth Way, Pasadena, $3.35 \mathrm{~km}$. $\mathrm{NE}$ of SL. About 500 to 600 feet $(150 \pm \mathrm{m}$.) of old alluvium over crystalline rock. Instrument $\mathrm{E}$ in garage which is part of one-story frame house, January 3 to 14 , 1957.

CIT. Athenaeum on California Institute of Technology campus, 1201 East California Street, Pasadena, $4.75 \mathrm{~km}$. ESE of SL. Roughly 900 feet (250 to $300 \mathrm{~m}$.) of old alluvium over crystalline rock. Ground water 100 to 200 feet below surface. Instruments in basement of $2 \frac{1}{2}$-story reinforced concrete building; see Gutenberg and Richter (1956, p. 112) and Gutenberg (1956). Instrument A, N-S component, 


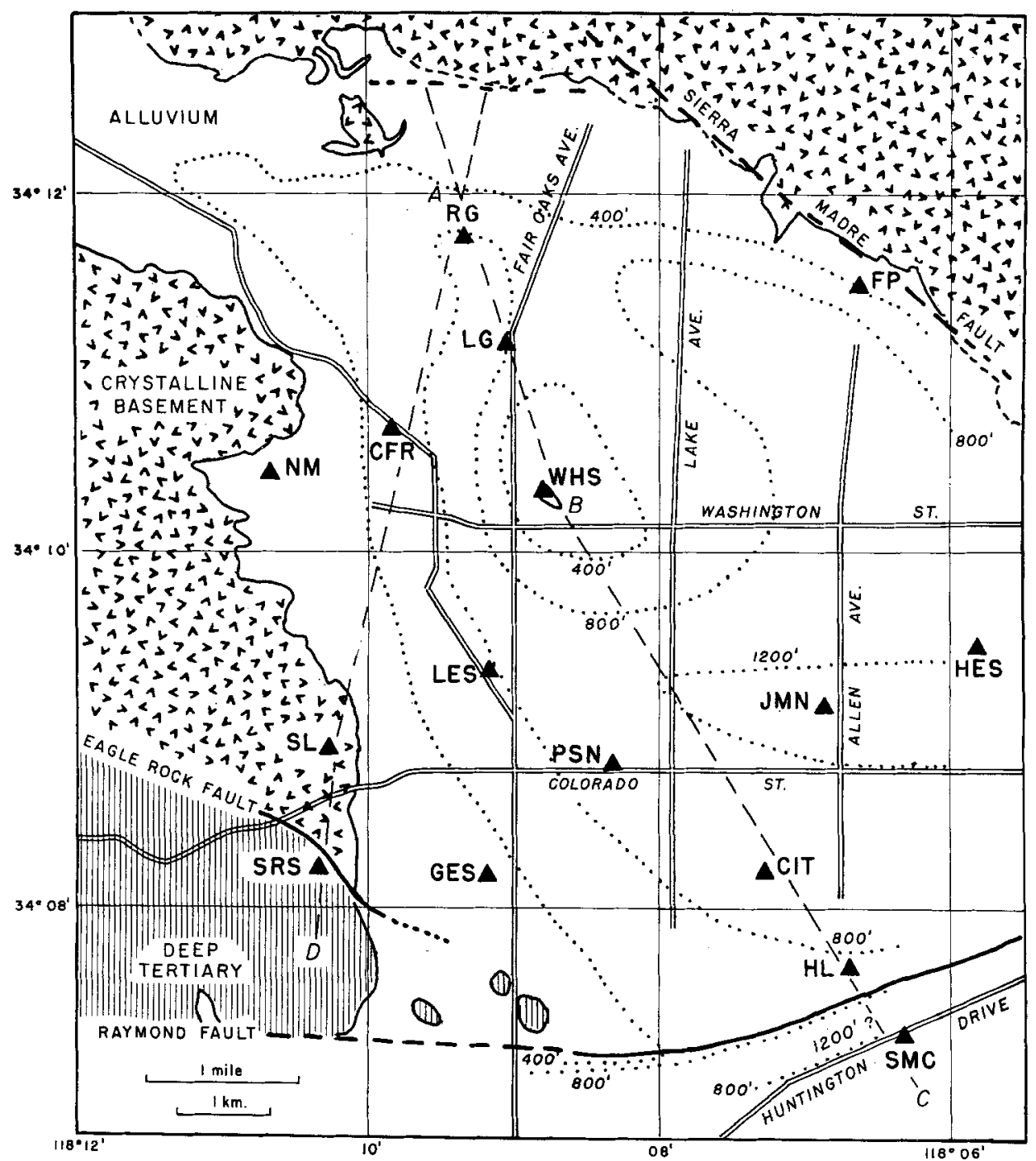

Fig. 5. Location of sites north of Raymond fault. Dotted lines indicate the estimated thickness in feet of old alluvium resting on crystalline rock north of the Raymond fault and on Tertiary sediments south of it. For profiles $\mathrm{ABC}$ and $\mathrm{AD}$ see figures 7 and 8 .

February 3 to March 15, 1955; Instrument C, E-W component, November 5, 1956, to March 4, 1957.

$F P^{*}$. Residence of Dr. Frank Press, 1972 Skyview Drive, Altadena, $7.3 \mathrm{~km}$. NE of SL. Several hundred feet $(150$ ? $\mathrm{m}$.) of old alluvium on crystalline rock. About $1 / 4 \mathrm{~km}$. SW of Sierra Madre fault and outcrop of crystalline rock. Instrument B in basement of 2-story frame building, January 3 to 11, 1957.

GES. Garfield Elementary School, 540 South Pasadena Avenue, Pasadena, 2.13 $\mathrm{km}$. SE of SL. Roughly 300 feet $(100 \mathrm{~m}$.) of old alluvium on crystalline rock. About 


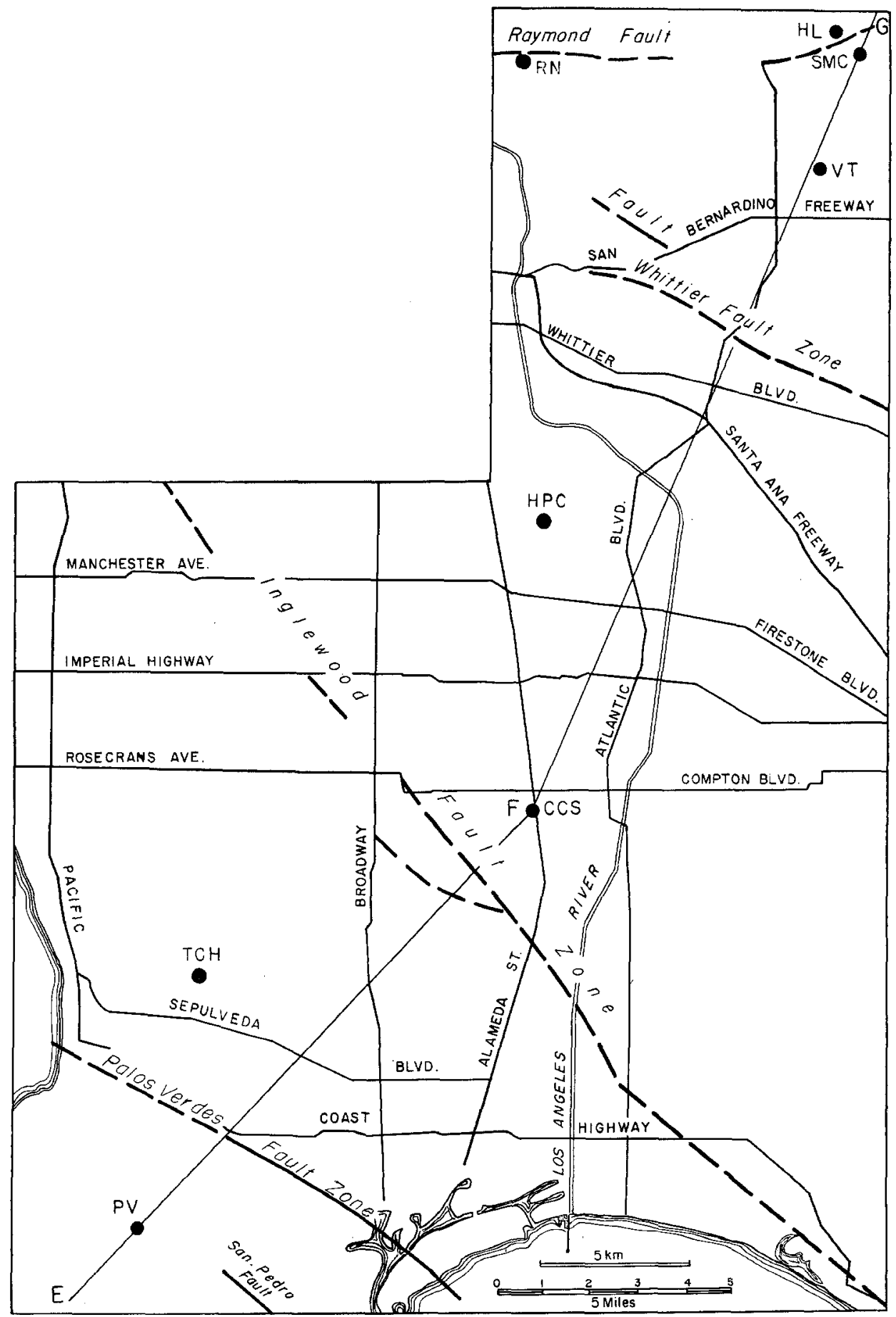

Fig. 6. Location of sites south of Raymond fault. For profile EFG see figure 9. 


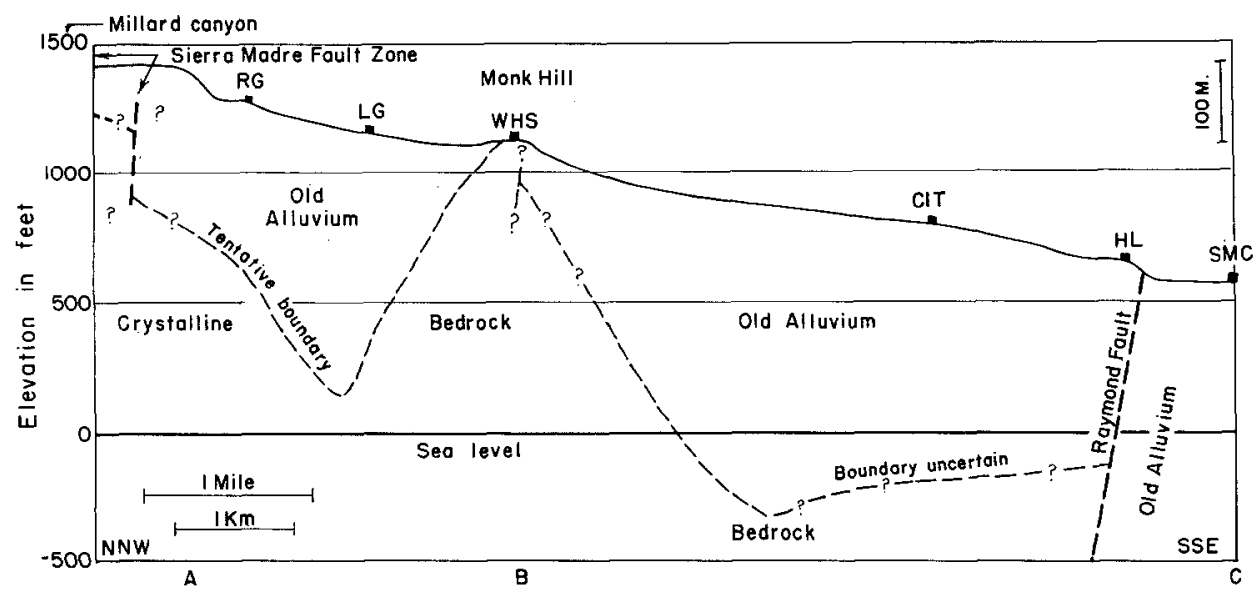

Fig. 7. Profile ABC (fig. 5). For sources see text.

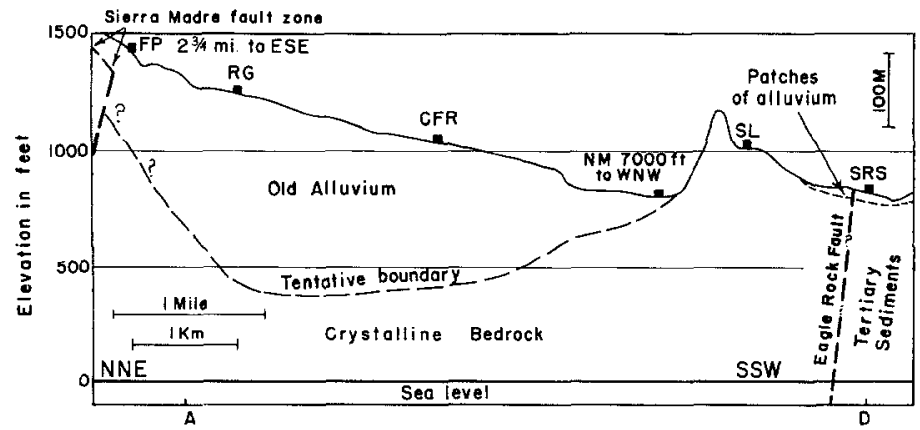

Fig. 8. Profile AD (fig. 5). For sources see text.

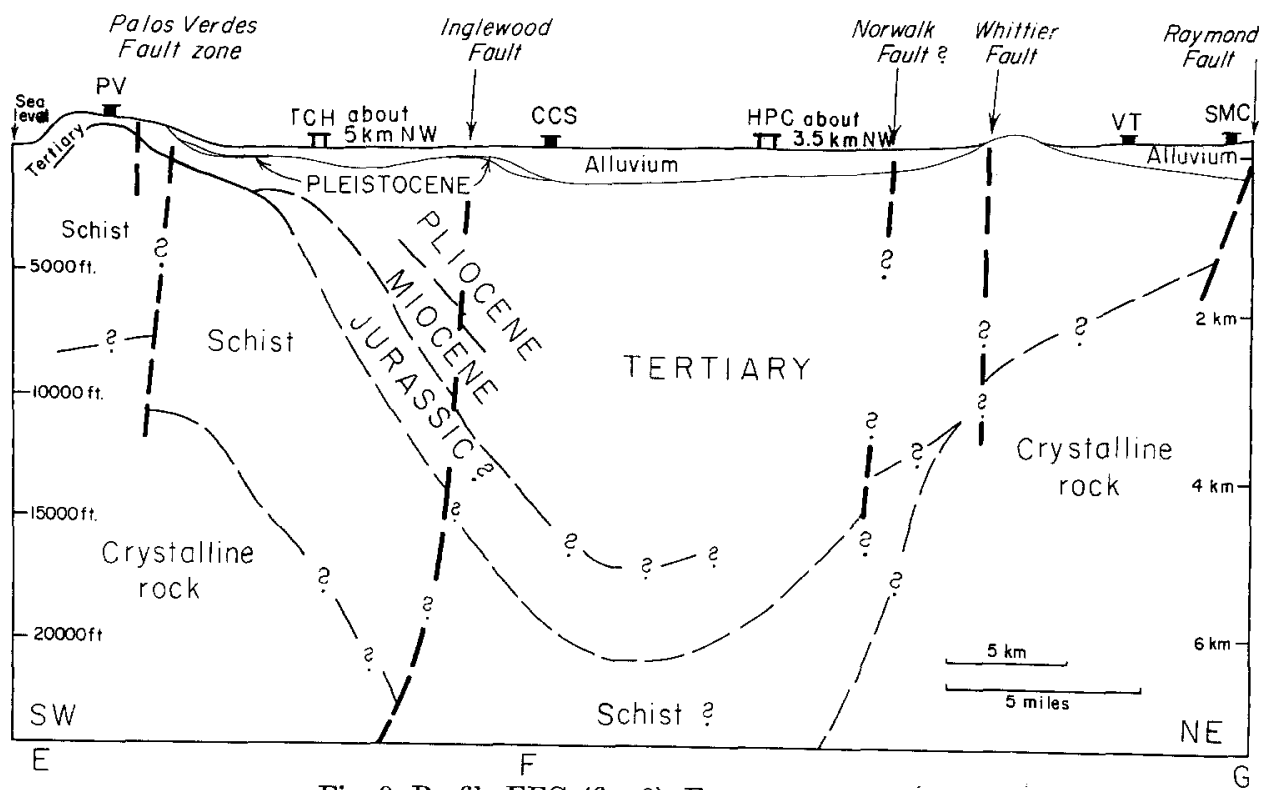

Fig. 9. Profile EFG (fig. 6). For sources see text. 
$800 \mathrm{~m}$. NE of Eagle Rock fault and about $700 \mathrm{~m}$. E of outcrop of crystalline rock. Instrument $\mathrm{E}$ in basement of 2-story concrete building, January 14 to 31, 1957.

HES. Hale Elementary School, 2550 Paloma Street, Pasadena, $6.9 \mathrm{~km}$. ESE of SL. Roughly 1,000 feet $(300 \mathrm{~m}$.) of old alluvium over crystalline rock. Instrument A in basement of one-story frame building, January 15 to February 4, 1957.

$H L$. Huntington Library, 1151 Oxford Road, San Marino, $5.93 \mathrm{~km}$. ESE of SL. About $200 \mathrm{~m}$. north of Raymond fault on roughly 700 feet $(200 \mathrm{~m}$.) of old alluvium over crystalline rock. Ground-water level roughly 100 feet below surface. Instrument $\mathrm{B}$ in basement of 3 -story reinforced concrete building, October 30 to December $17,1956$.

$H P C$. Huntington Park City Hall, at Miles Avenue and Zoe Avenue, Huntington Park, $181 / 2 \mathrm{~km}$. SSW of SL. Probably somewhat more than 1,000 feet $(400 \pm \mathrm{m}$.) of old alluvium over roughly 3 miles $(5 \pm \mathrm{km}$.) of Tertiary sediments, resting probably on (Jurassic?) schist. Water level 100 to 150 feet (30 to $50 \mathrm{~m}$.) below the surface. Instrument $\mathrm{A}$ in basement of 2-story concrete building, March 1 to 15, 1957.

$J M N^{*}$. Residence of Mr. John M. Nordquist, 1695 Corson Street, Pasadena, $4.84 \mathrm{~km}$. east of SL. Probably roughly 1200 feet $(350 \mathrm{~m}$.) of old alluvium over crystalline rock. Water table $250 \pm$ feet below surface. Instrument A in garage not connected with one-story frame building, February 4 to $21,1957$.

$L G$. Instrument factory of Lehner and Griffith, 2329 North Fair Oaks Avenue, Altadena, $4.6 \mathrm{~km}$. NNE of SL. About 800 feet $(250 \mathrm{~m}$.) of old alluvium over crystalline rock. Instrument $\mathrm{E}$ in basement of one-story cement block building, December 12 to $28,1956$.

$M t W$. Instrument building of Seismological Laboratory, south of 60 -inch dome of Mount Wilson Observatory of Carnegie Institution of Washington, $13.6 \mathrm{~km}$. NE of SL, on crystalline granitic rock. Instrument $A$ and one other torsion seismograph on pier in one-story frame building, 1928-1951. (See Gutenberg, 1956b.)

$N M^{*}$. Residence of Mr. N. Motta, 1545 Ontario Avenue, Pasadena, $2.92 \mathrm{~km}$. NNW of SL. Probably less than 100 feet $(25 \pm \mathrm{m}$.) of old alluvium over crystalline bedrock which crops out $1 / 4 \mathrm{~km}$. to north. Instruments $\mathrm{E}$ (December 28, 1956, to January 3, 1957) and B (February 1 to 20, 1957) on concrete slab of hobby shop, about 20 feet from one-story frame house.

PSN. Pasadena Star-News, 525 East Colorado Street, Pasadena, $2.95 \mathrm{~km}$. east of SL. Probably roughly 900 feet (250 to $300 \mathrm{~m}$.) of old alluvium over crystalline rock. Instrument $\mathrm{E}$ in basement of 4-story reinforced concrete building, January 31 to February 11, 1957.

$P V$. Palos Verdes, School District Administrative Center, 38 Crest Road, Palos Verdes, $46 \mathrm{~km}$. SSW of SL. Patches of alluvium over several hundred feet (roughly $100 \mathrm{~m}$.) of Tertiary sediments resting on (Franciscan?) schist. Instrument B on ground floor of one-story light frame building, February 20 to March 15, 1957.

$R G^{*}$. Residence of Mr. R. Gilman, 416 Devirian Place, Altadena, $5.47 \mathrm{~km}$. NNE of SL. About 800 feet $(250 \mathrm{~m}$.) of old alluvium over crystalline rock. About one mile south of Sierra Madre fault and outcrop of crystalline rock. Instrument B on floor of garage attached to one-story frame building, December 17, 1956, to January 3,1957 . 
$R N$. Residence of Mrs. E. Frackelton, 3950 Scandia Way, Los Angeles, opposite to residence of Mr. R. Nielsen*, $6.4 \mathrm{~km}$. SW of SL. On deep Tertiary sediments, in Raymond fault zone, probably about $100 \mathrm{~m}$. south of main fault which here separates Topanga formation (Middle Miocene) to the north from the Yorba member of the Puente formation (Upper Miocene) to the south; some alluvium in a narrow valley north of the building. Instrument $\mathrm{C}$ in garage built into hill, not connected with stucco building, March 4 to $14,1957$.

SL. Seismological Laboratory, 220 North San Rafael Avenue, Pasadena. On crystalline rock of granitic character, weathered near surface. About $300 \mathrm{~m}$. to the east the rock dips under alluvium; about $1 \mathrm{~km}$. to $\mathrm{SW}$ is the Eagle Rock fault which separates the crystalline rock from thick Tertiary sediments of Middle Miocene. Instruments I and II on pier in recording room; other instruments have been tested on pier of adjoining experimental recording room, both on ground floor of 2-story reinforced concrete building.

SMC. San Marino City Hall, 2200 Huntington Drive, San Marino, 6.7 km. ESE of SL. Probably roughly 1,200 to 1,500 feet $(500 \pm \mathrm{m}$.?) of old alluvium over several thousand feet (roughly $1 \mathrm{~km}$.?) of Tertiary sediments resting on crystalline rock. Between SMC and HL (about $900 \mathrm{~m}$. NW of SMC) is the Raymond fault; to the north of this fault crystalline rock is much closer to the surface than to the south. Ground-water level probably roughly 300 feet below surface. Instrument D in basement of 2-story reinforced concrete building, January 28 to February 12, 1957.

SRS. San Rafael Elementary School, 1090 Nithsdale Road, Pasadena, $1.22 \mathrm{~km}$. south of SL. On Tertiary Topanga stratified sediments with scattered patches of alluvium on top. Surface of crystalline rock probably several thousand feet (roughly $1 \mathrm{~km}$. ?) deep. The Eagle Rock fault which separates crystalline rock to the north from Tertiary to the south is about $50 \mathrm{~m}$. (100 to $200 \mathrm{ft}$.) north of SRS. Instrument $\mathrm{D}$ on ground floor of 2-story reinforced concrete building, November 28, 1956, to January 28, 1957.

TCH. New Torrance City Hall, 3031 Torrance Boulevard, $37 \mathrm{~km}$. SW of SL. Roughly 1,000 feet of alluvium, some of it recent, over several thousand feet of Tertiary, resting on (Jurassic?) schist. Ground water about 100 feet below surface. Instrument $A$ in basement of 3-story reinforced building, February 25 to March 1, 1957.

$V T^{*}$. Residence of Mrs. Violet Taylor, 1033 South Almansor Street, Alhambra, $8.6 \mathrm{~km}$. SE of SL. Roughly 1,000 feet $(300 \pm \mathrm{m}$.) of old sediments over several thousand feet ( 1 to $2 \mathrm{~km}$.?) of Tertiary sediments resting probably on crystalline rock. Ground-water level probably roughly 150 feet below surface. Instrument D on floor of garage, separated from one-story frame building, February 12 to March 14, 1957.

WJS. Washington Junior High School, 1490 North Raymond Avenue, Pasadena, $4.56 \mathrm{~km}$. NNE of SL. On crystalline rock (Monk Hill) surrounded by alluvium; radius of outcrop about $100 \mathrm{~m}$. (300土 feet). Instrument $A$ on ground floor of onestory building in old part of school on NE portion of hill, December 18, 1956, to January 15, 1957. 


\section{The Records; General Results}

In addition to records published previously (Gutenberg and Richter, 1956; Gutenberg, $1956 a, b)$, examples of records written simultaneously at several stations are reproduced, e.g., in figures 10 to 12 . Several results found for CIT and MtW (Gutenberg, 1956a, b) may now be generalized. For example, the periods of corresponding waves may differ significantly at some of the various sites (compare center of figs. 13 and 14). Moreover, waves having relatively short periods may be emphasized by ground conditions at some sites (e.g., at SRS, fig. 10) and waves having appre-
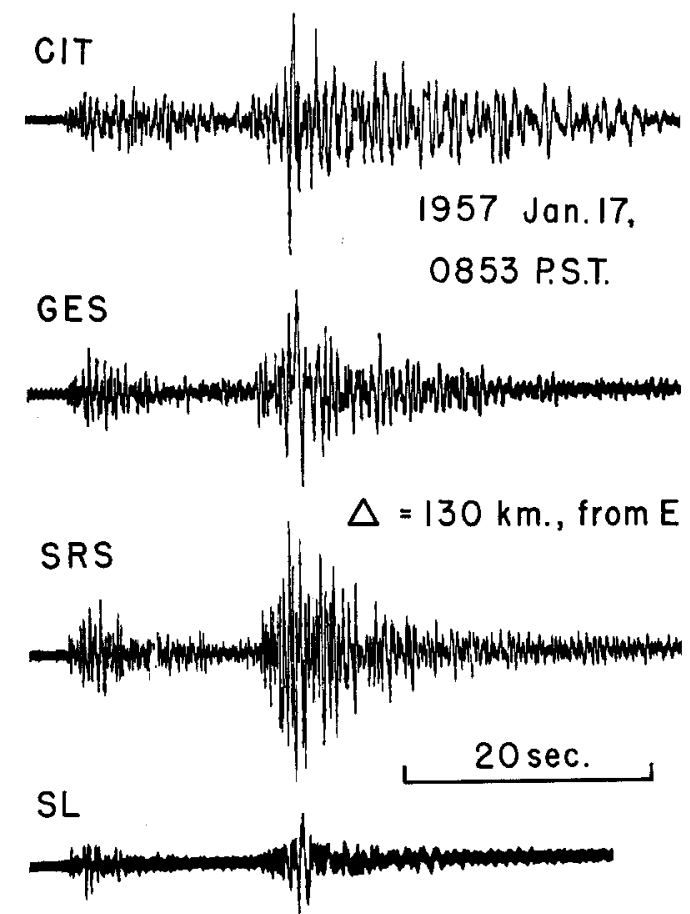

Fig. 10. Seismograms of earthquake of January 17,1957 , magnitude $3 \frac{3}{4} \pm$; waves arriving from east.

ciably longer periods at others (e.g., at CIT, figs. 11 and 12). Consequently, the ratio of the maximum in the $\mathrm{P}$ group as well as the $\mathrm{S}$ group recorded at a given site to the corresponding maximum at another site, especially at SL, depends on the wave period. Differences in periods of a given wave are probably of less importance to engineers in designing earthquake resistant structures than the "resonance" periods to be discussed later in more detail.

Usually, the onsets of new phases in seismograms of shocks record with rather small differences at most sites, but later waves in the $\mathrm{P}$ group or the $\mathrm{S}$ group are frequently appreciably larger and the duration of "relatively strong shaking" is greater at sites on deep alluvium than at those on crystalline rock. (Figs. 13 to 15.) 


\section{Effect of Ground on the Duration of Relatively Strong Shaking}

Gutenberg (1956a) has found that "relatively strong shaking continues on the campus a few times as long as at the Seismological Laboratory" (see also figs. 13 and 14). "Relatively strong shaking" has to be defined for each shock. For small shocks the duration of motion clearly visible on the records was used; for large records, the duration of motion with trace amplitudes exceeding a given amount. The results are

\section{Dec. 31, 0938 and 0940 P.S.T. $\quad 30$ sec.}

RG

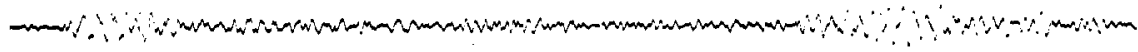

WHS

NM

$S L$

SRS

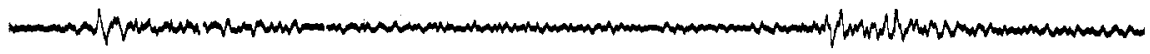

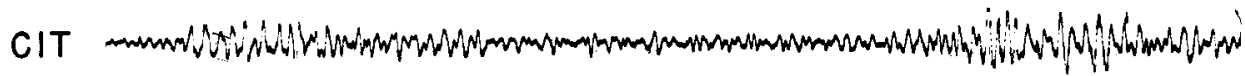

Fig. 11. S groups in seismograms of two Nevada shocks, magnitude about 5, distance about $500 \mathrm{~km}$. The second shock followed the first after about $1 \frac{1}{4} \mathrm{~min}$.

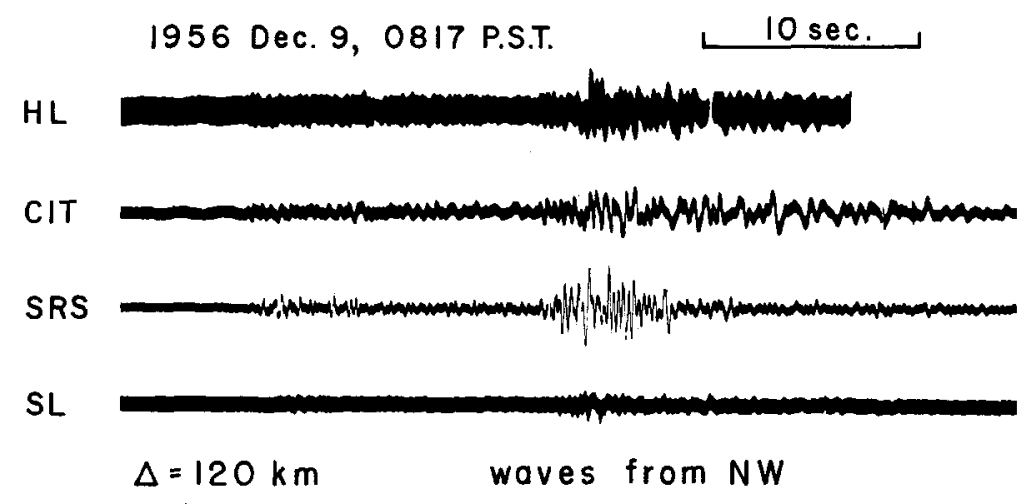

Fig. 12. Seismograms of earthquake of December 9,1956 , magnitude $31 / 4$.

affected by the level of the continuous unrest of the ground, and for this reason the "duration" has been underestimated for most data obtained at sites in the Los Angeles Basin (CCS and HPC). In table 1 are listed average ratios of "relatively strong shaking" recorded on fairly dry alluvium to that recorded simultaneously at SL. The standard errors of most values of $\mathrm{R}$ do not exceed 0.3 .

At VT and CCS, where the alluvium has a thickness $D$ of at least 1,000 feet, and the water table is within 200 feet of the surface, $R=23 / 4(n=17)$ and $R \geqq 3$ $(n=5)$ respectively. At HPC the continuous unrest of the ground is too large to find $R$. On Tertiary, $R=2.4(n=31)$ at SRS (patches of alluvium on deep Ter- 
tiary); at $\mathrm{RN}, R=2.4(n=8)$; at $\mathrm{PV}$ (frequently disturbed by microseisms) $R=2 \pm(n=6)$.

In interpreting values of $R$ (as in other discussions in the present paper) it has to be considered that alluvium includes materials with widely differing properties, such as sand, gravel, and clay; their distribution in depth differs greatly from place to place. Tertiary materials have even more divergent properties. Moreover, the depth of the water table affects $R$. However, separation of values of $R$ at SRS before and after January 4, 1957 (beginning of a rainy period), did not indicate a signifi-

TABLE 1

Average Ratio $R$ of Duration of "Relatively Strong Shaking" at Sttes on Alluvtum in the Pasadena Area to that at the Seismological Laboratory (SL)

$(\mathrm{D}=$ assumed thickness of the alluvium, frequently doubtful, in feet; $n=$ number of records of near-by earthquakes used.)

\begin{tabular}{|c|c|c|c|c|c|c|c|c|c|c|c|}
\hline Site & $D$ & $n$ & $R$ & Site & $D$ & $n$ & $R$ & Site & $D$ & $n$ & $R$ \\
\hline MtW. & $\begin{array}{r}\text { ft. } \\
0\end{array}$ & $\begin{array}{l}\text { no. } \\
25\end{array}$ & 1.5 & CFR. & $\begin{array}{c}\text { ft. } \\
550\end{array}$ & $\begin{array}{r}\text { no. } \\
4\end{array}$ & 3.5 & PSN. & $\begin{array}{l}\mathrm{ft} . \\
900\end{array}$ & $\begin{array}{r}\text { no. } \\
5\end{array}$ & 3.2 \\
\hline WHS. & 0 & 18 & 1.3 & HL. . & $700 ?$ & 11 & 3.0 & CIT. & 900 & 50 & 4.1 \\
\hline NM. . & 50 & 17 & 1.5 & LES. & 700 & 8 & 4.3 & HES. . & 1,000 & 8 & 4.5 \\
\hline GES. & 300 & 6 & 1.6 & LG. . & 800 & 10 & 2.1 & JMN. & 1,200 & 10 & 4.0 \\
\hline FP. & $500 ?$ & 5 & 4.5 & RG. . & 800 & 13 & 2.3 & SMC. & $1,500 ?$ & 11 & 4.6 \\
\hline
\end{tabular}

TABLE 2

Average Composition of Alluvium in Different Parts of the San Gabriel Basin

(Data after Eckis, 1934, pp. 130, 148. See also his plate 8, following p. 58. All sites in the basin for which seismograms have been obtained are either in the Arroyo or in the western area.)

\begin{tabular}{|c|c|c|c|}
\hline Area & Clay & Sand & Gravel \\
\hline Arroyo.... & $\begin{array}{c}\text { per cent } \\
48\end{array}$ & $\begin{array}{c}\text { per cent } \\
0\end{array}$ & $\begin{array}{c}\text { per cent } \\
52\end{array}$ \\
\hline Western................ & 43 & 9 & 48 \\
\hline Northeast central. ................... & 11 & 13 & 76 \\
\hline Southwest central. . . . . . . . . . . . . . & 27 & 27 & 46 \\
\hline Eastern $\ldots \ldots \ldots \ldots \ldots \ldots \ldots \ldots \ldots$ & 74 & 8 & 18 \\
\hline
\end{tabular}

cant difference; seasonal differences in the water table in the Pasadena area are roughly 20 feet.

All values for $R$ are relative to the duration of "strong shaking" at SL. This cannot be expected to be free from local effects, and, owing to relatively small amplitudes, is often not so well determined as the corresponding duration at the other stations.

For CIT, values of $R$ have been plotted (not reproduced) as function of the prevailing periods $T$. For the few occurrences when $T<1 / 2$ sec. at CIT, $R=3 \pm$; if $1 / 2<T<3 / 4$ sec., $R=4$; for four earthquakes distant less than $500 \mathrm{~km}$. with $T \geqq 1$ sec., $R$ is again about 3 . For shocks originating at distances $\triangle>500 \mathrm{~km}$., the "duration of strong shaking" has not been determined. 
It follows (see also fig. 22,a) that usually "relatively strong shaking" lasts longer at sites on deep alluvium than at those on thin alluvium or on crystalline rock.

\section{Periods for Which "Ground Response" is Relatively Large}

In records written at some sites, waves are regularly emphasized that have appreciably shorter periods $T$ than those in records written at other sites (see, e.g., fig. 16). Since this indicates a functional relationship between amplitudes and periods,

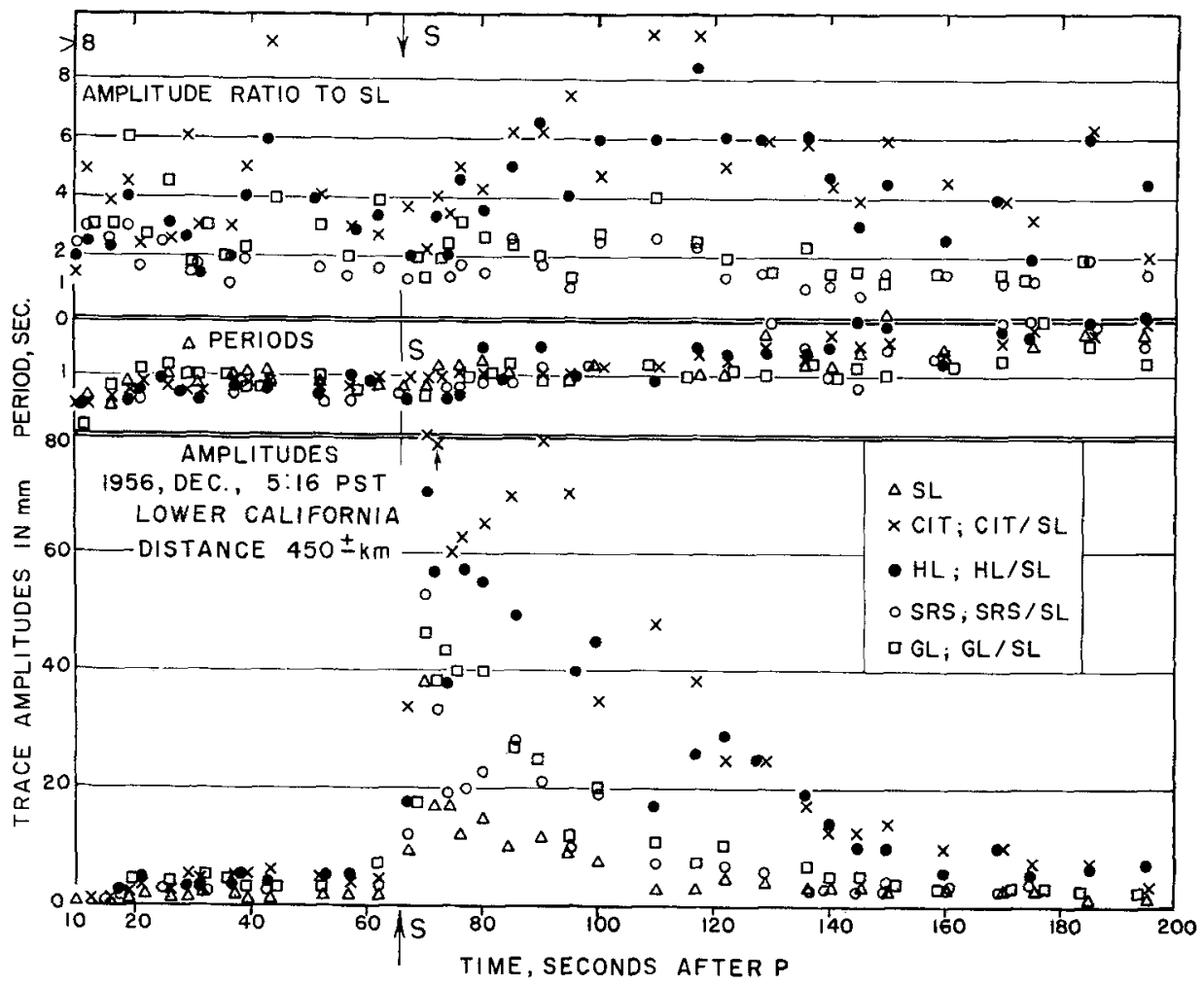

Fig. 13. Trace amplitudes (bottom), periods (center), and amplitude ratios (top) as function of time after $\mathrm{P}$ in Lower California earthquake of December 13, 1956, magnitude about 6.

ratios of maxima in well-recorded $\mathrm{P}$ phases and in $\mathrm{S}$ phases at all operating stations to the maxima in the corresponding phases at SL have been plotted as function of $T$. Occasionally, recorded amplitudes of surface waves of teleseisms could also be used, and a few amplitudes of microseisms have been compared.

At sites close to SL no corrections for differences in epicentral distance are necessary. However, when these differences exceed about $10 \mathrm{~km}$., such corrections are taken from figure 17 separately for $P$ (based on Gutenberg, 1951, p. 148), and for $\mathrm{S}$ (Richter, 1948, p. 223, on the assumption that in near-by shocks the largest trace amplitude of the record occurs in the $S$ group). No such correction was necessary for comparison of amplitudes in records of teleseisms. 
Since amplitudes recorded at SL are relatively small, ratios of amplitudes at a given site to those at CIT and VT have also been used. The resulting curves have been considered in drawing curves for ratios to SL. If corresponding maxima at two stations showed slightly different wave periods, greater weight was given to the period at the station under investigation.

Since, for a given site, ratios derived from $\mathrm{P}$ or $\mathrm{S}$ of near-by shocks, from $\mathrm{P}, \mathrm{S}$, or $\mathrm{L}$ of teleseisms, or from microseisms, do not show systematic differences, all have been combined. Figures 18 and 19 give examples of the results. The scattering of the

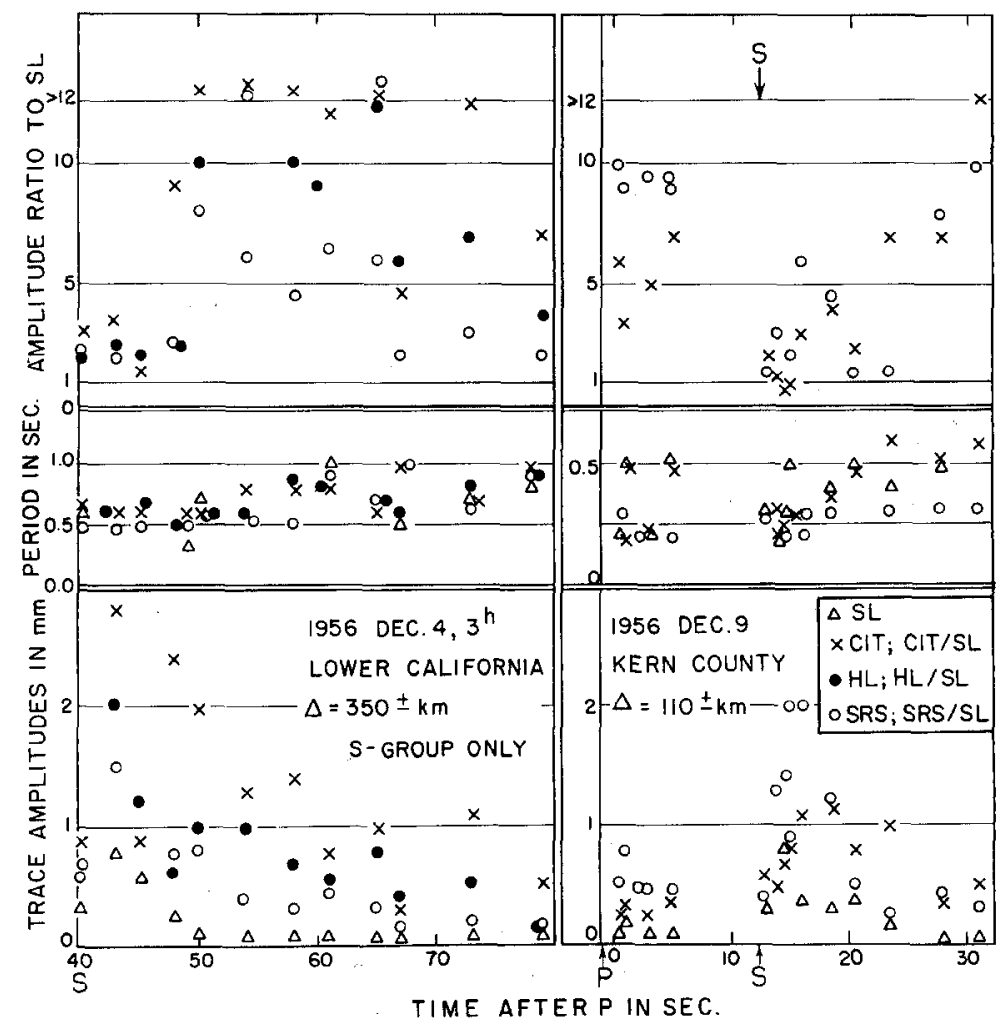

Fig. 14. Trace amplitudes (bottom), periods (center), and amplitude ratios (top) during $\mathbf{S}$ group of Lower California earthquake, magnitude about $5 \frac{1}{2}$ (at left), and (at right) during Kern County earthquake, magnitude $3 \frac{1}{4}$ (compare fig. 12). Note difference in period scale for the two shocks.

points is partly a consequence of errors in amplitude measurements (e.g., effect of thickness of the line) and errors of at least 0.1 sec. in the measured periods (paper speed $1 \mathrm{~mm}$. per sec.). Moreover, effects of different wave paths may be appreciable (Gutenberg, 1956a, pp. 205-206), considering the complicated geological structure of the region. No systematic differences have been found as function of the azimuth of the arriving waves. Some amplitude ratios show less scattering when plotted against the wave length than when plotted against the period (Gutenberg, 1956b, fig. 1). While the scattering of the data does not affect the main conclusions, details of some curves may be influenced by accidental accumulation of "errors." 
1957 Feb 19, 0844 P.S.T. $\quad \Delta=130 \pm k m$, from NNW NM -

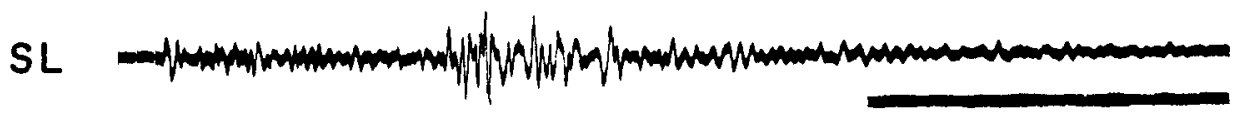

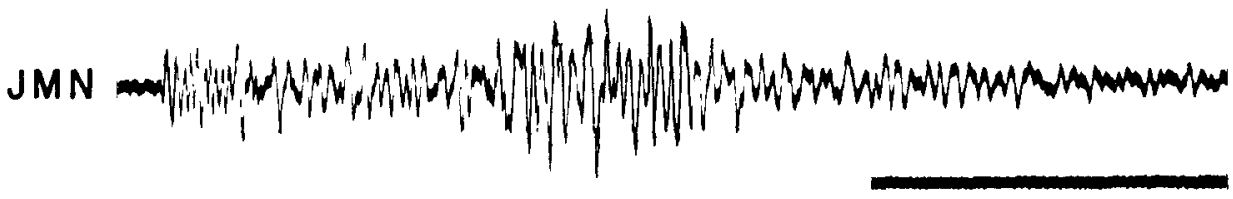

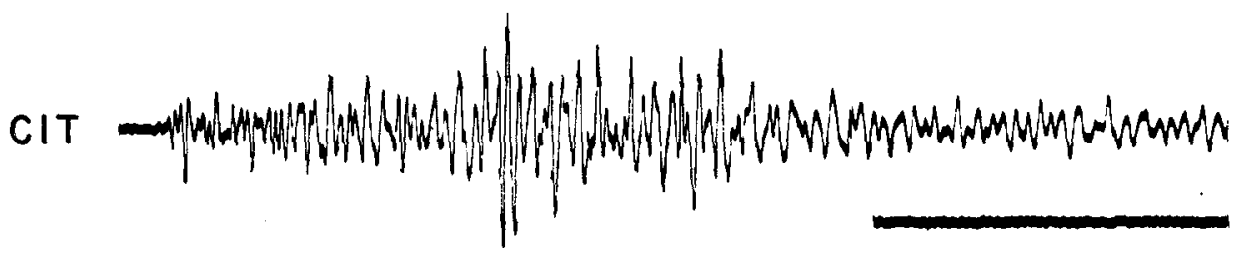

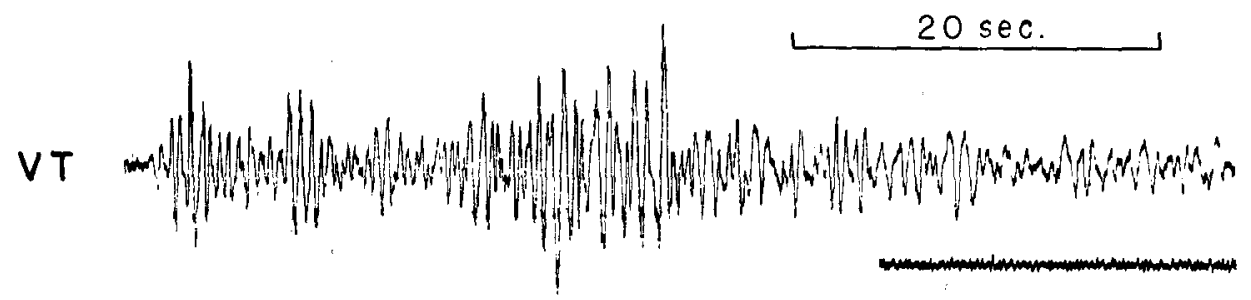

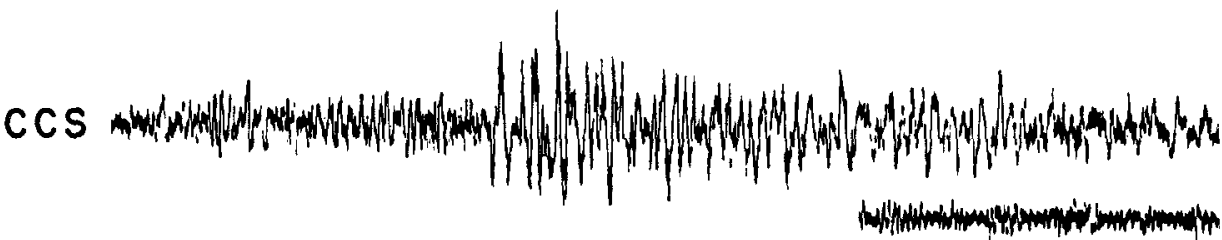

Fig. 15. Seismograms of Kern County shock, February 19, 1957, magnitude 4. At right, below each seismogram, record of background $15 \mathrm{~min}$. after earthquake.

Figure 20, $a$ shows average curves for the Raymond and San Gabriel basins, which are separated by the Raymond fault (figs. 5 and 7). All curves are similar irrespective of the thickness of sediments, except for the curve for FP (which is on only a few hundred feet of alluvium close to the outcrop of crystalline rock), and indicate a maximum response of the ground to waves having periods of between 1 and $11 / 2$ sec. The depth of the ground-water table increases northward from roughly 100 feet north of the Raymond fault to a few hundred feet in the central part of the basin; it is deeper immediately south of the Raymond fault (SMC) than north of it (HL). 
Figure 20, $b$ shows that curves for sites near the old Arroyo Seco valley are of a type differing clearly from the preceding. Although under some sites west of Monk Hill the alluvium is probably almost as thick (700 or 800 feet at LES, LG, RG) as to the south and east of Monk Hill, the greatest response (relative to SL) at sites in the Arroyo valley is found for waves having periods of only about $1 / 2$ sec. At NM, which is close to the outcrop of crystalline rock and on alluvium probably less than 100 feet thick, amplitudes of waves having periods of about $1 / 4$ sec. may be relatively large (fig. 15, top of figure 19).

Figure 20, $b$ indicates that at most sites in the Arroyo valley the response of the ground for waves having periods of about 5 sec. is smaller than at SL. This may result from conditions at SL. It was not possible to find the "absolute" response curve for SL.

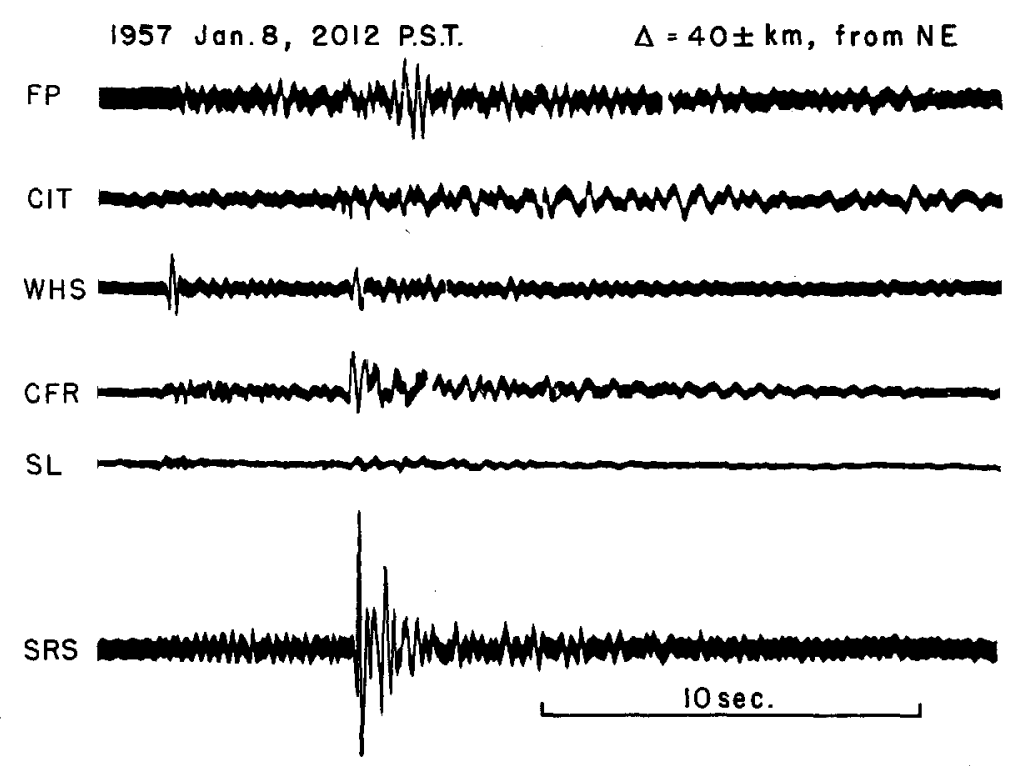

Fig. 16. Seismograms of shock of January 8, 1957, magnitude $21 / 2$, waves from NE, in order of increasing $\Delta$. Note difference between SRS and SL, less than one mile apart, and relatively large long-period waves at CIT.

The systematic differences between the response of the ground over the basins to the east and to the west of Monk Hill may be affected by the difference in width of these basins (fig. 7), but differences in the types of alluvial sediments may also play a role. Moreover, the average ground-water level seems to be somewhat closer to the surface in the Arroyo basin than to the east of Monk Hill.

The response curves for the three sites on Tertiary (fig. 20,c) agree well among themselves although the sites are relatively far apart, the physical properties of Tertiary material differ even more than those for alluvium, and patches of alluvium cover the Tertiary at SRS and PV. The ground motion from waves having periods of $1 / 4$ to $1 / 2 \mathrm{sec}$. is appreciably larger than that at SL, but the response of the ground for waves having periods in excess of 1 sec. approaches that at SL.

The site in the Los Angeles Basin closest to the coast where an instrument had 


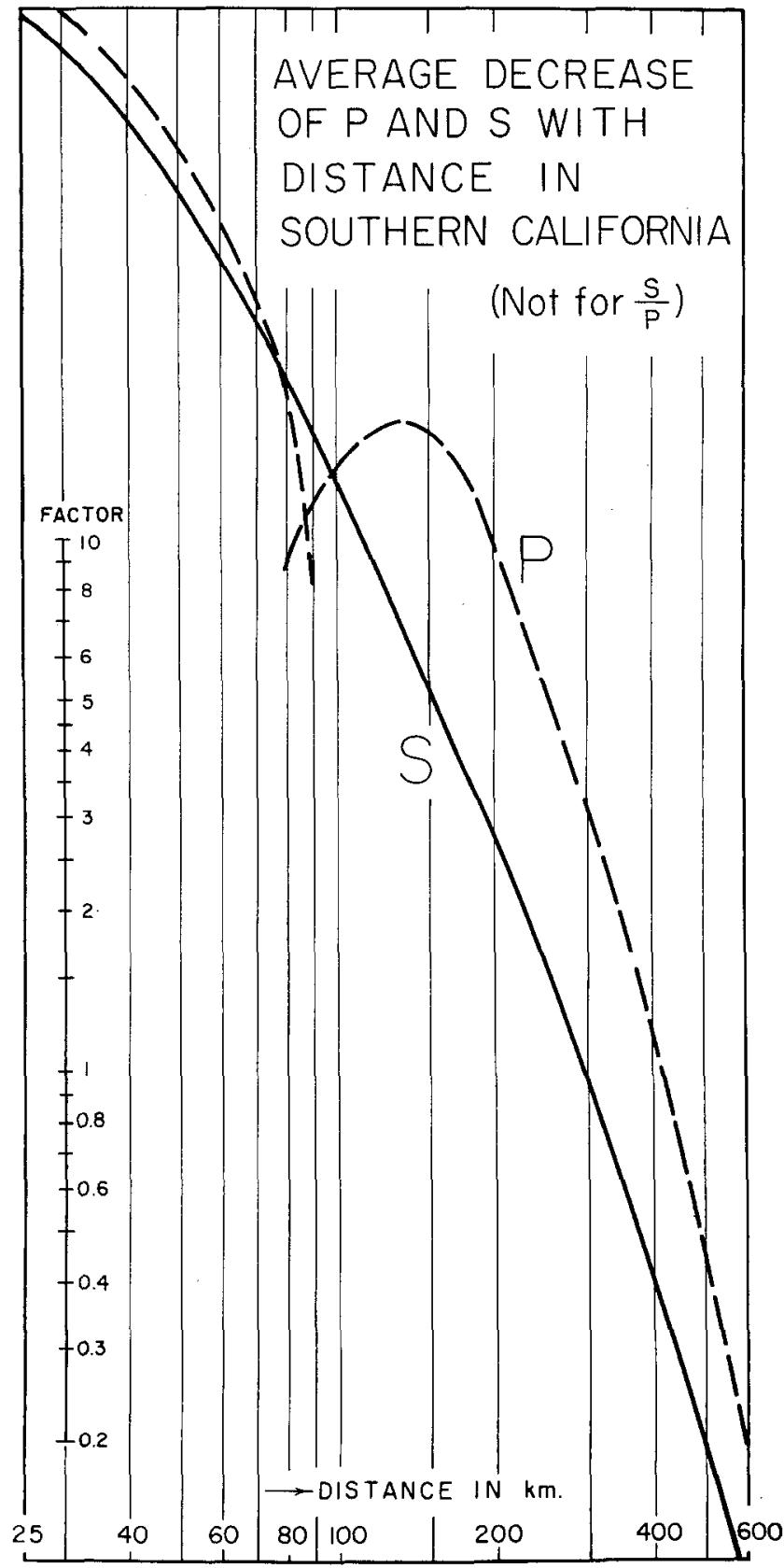

Fig. 17. Average change in maximum amplitudes of $\mathrm{P}$ group and $\mathrm{S}$ group with distance $\Delta$ in southern California. Logarithmic scales; the base lines for $\mathbf{P}$ and for $\mathbf{S}$ differ. 
been installed was at Torrance (TCH, see fig. 6). During four days of operation the unrest of the ground was so large that successive lines on the records overlapped continuously day and night and no records of earthquakes written by the standard torsion seismograph could be investigated. Frequently, waves having trace ampli-
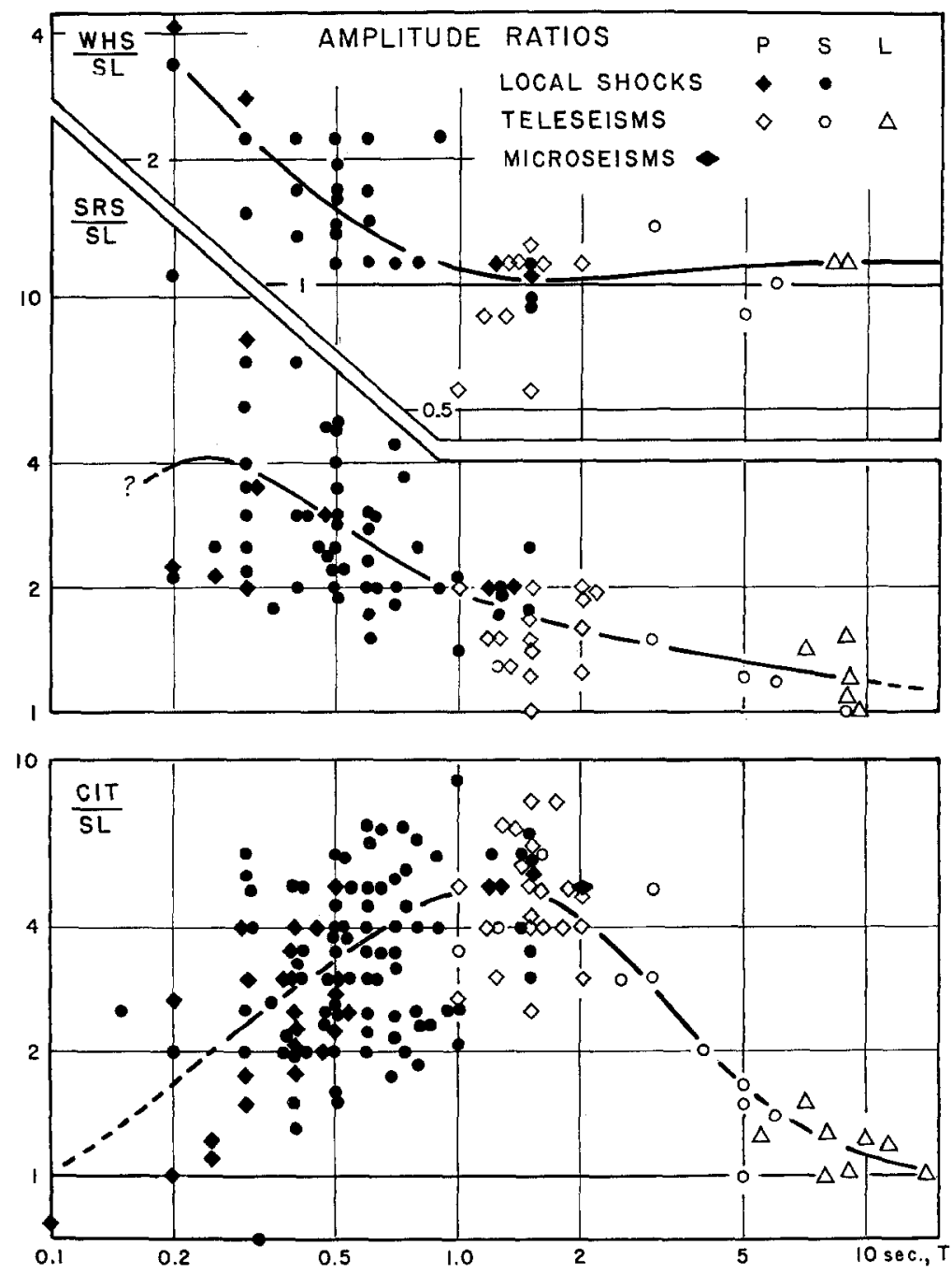

Fig. 18. Observed ratios of maximum trace amplitudes in various phases to those at SL as function of period $T$ at WHS, SRS, and CIT. Values for $T<0.2$ sec. are doubtful.

tudes of up to $5 \mathrm{~mm}$. and periods of 0.2 to $0.3 \mathrm{sec}$. could be distinguished at the margins, corresponding to ground amplitudes of $0.002 \mathrm{~mm}$. At HPC the background was somewhat smaller, with maxima of trace amplitudes frequently reaching $1 \frac{1}{2}$ $\mathrm{mm}$. (periods 0.2 to $0.5 \mathrm{sec}$.) regardless of the time of day or night (compare fig. 21). Still smaller background was recorded at CCS (fig. 15, bottom at right), but at CCS 
there is a difference between day (about $1 \mathrm{~mm}$.) and night (about $1 / 2 \mathrm{~mm}$.), indicating effects of traffic and industry.

At CCS and HPC the ground response is large for waves having an unusually wide range of periods. Relatively great amplitudes are recorded regularly for waves
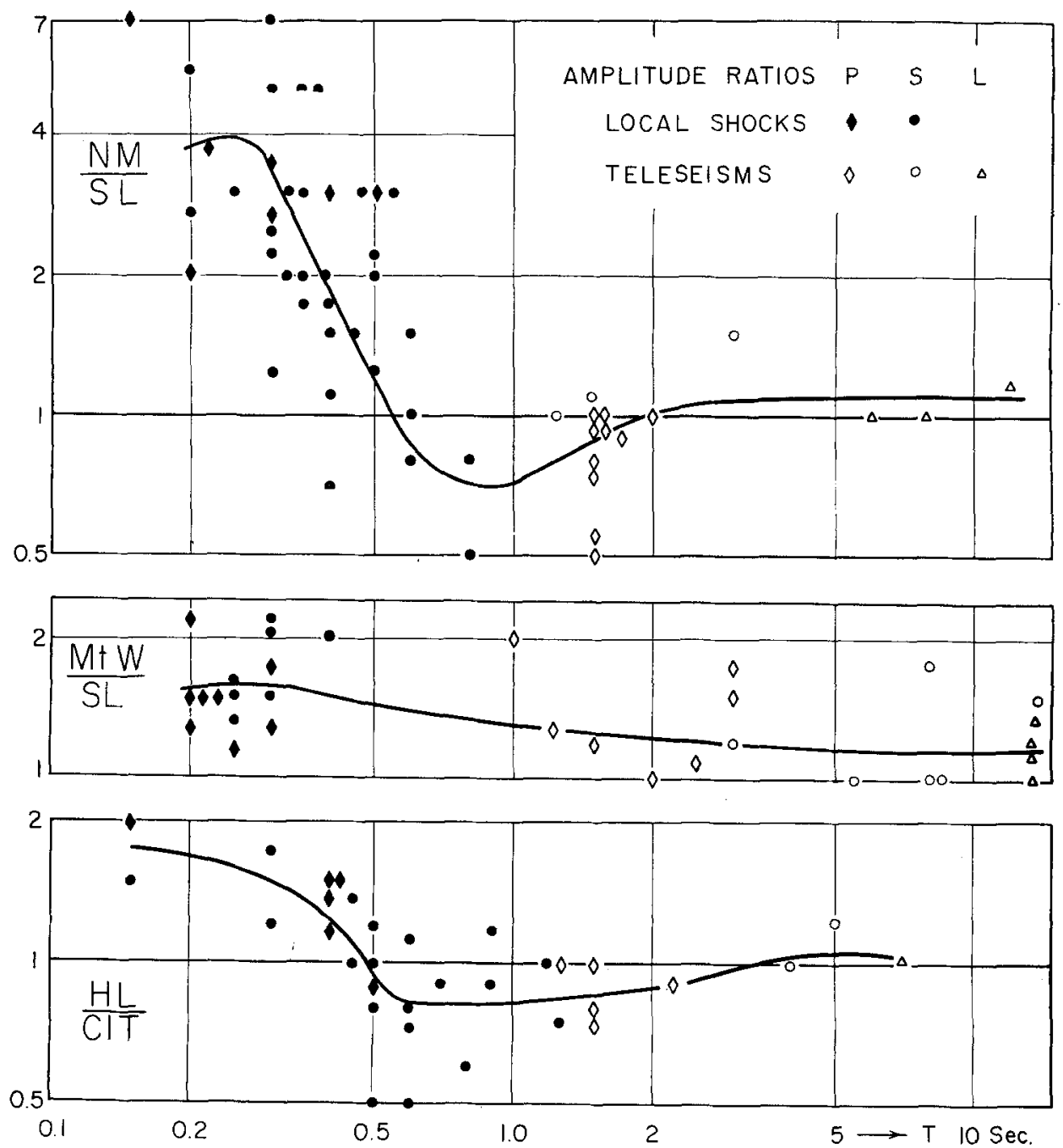

Fig. 19. Observed ratios of maximum trace amplitudes in various phases at $\mathrm{NM}$ and $\mathrm{MtW}$ to those at SL, and at HL to those at CIT, as function of period $T$.

having periods between $0.4 \mathrm{sec}$. (or less) and $7 \mathrm{sec}$. (fig. 20, c). Since earthquake waves having periods $T<0.4$ sec. appear only in small shocks, they could not be separated on records at either site from the background (compare fig. 21). If $T$ increases beyond 6 sec., the response of the ground relative to that at SL decreases, but even for waves having periods of 9 sec. the difference in response at CCS or HPC and that at other sites is always obvious (see fig. 21). 

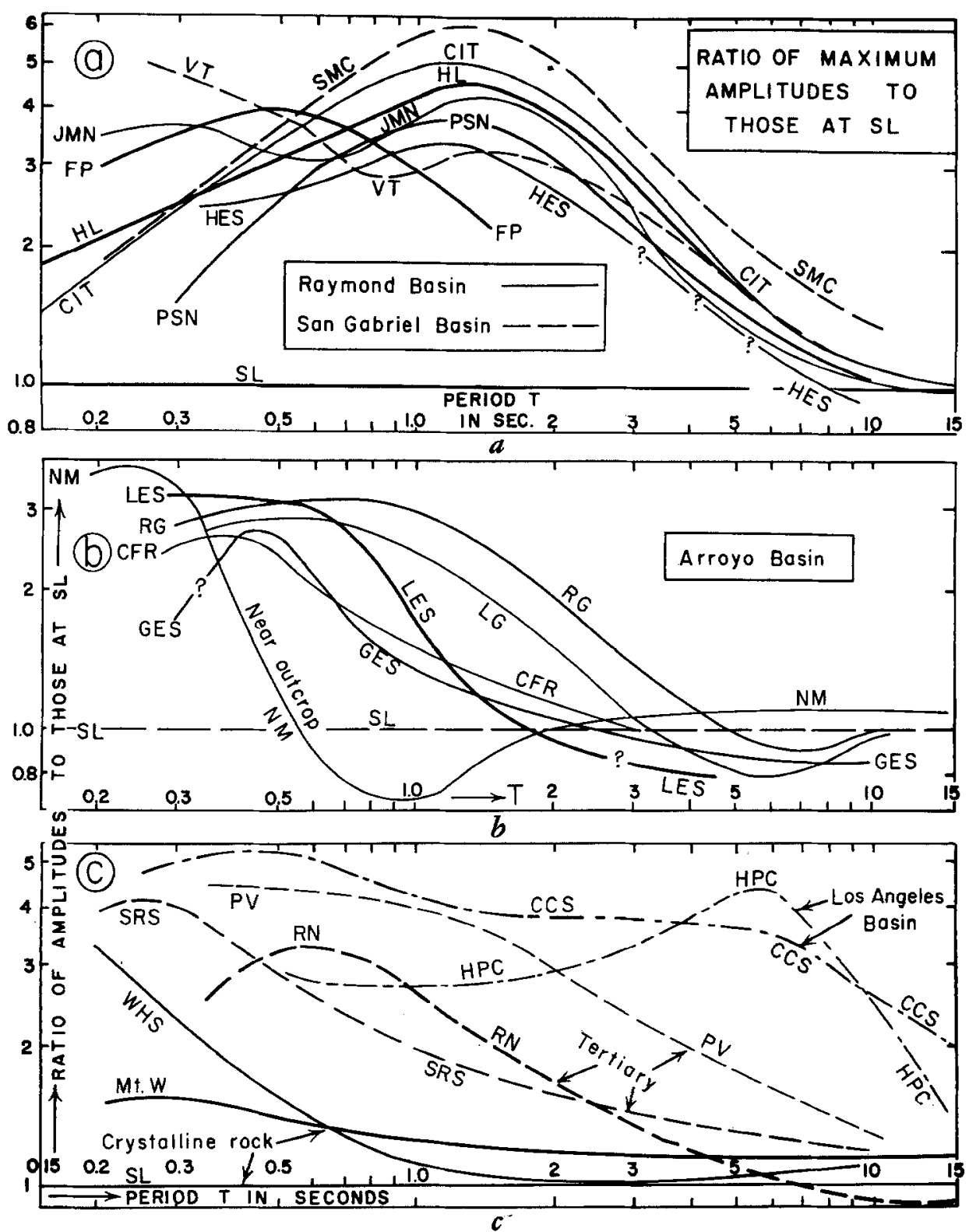

Fig. 20. Average observed ratios of trace amplitudes to those at SL as function of period $T$.

Data for VT in Alhambra have been plotted in figure 20, a. Subsurface conditions at SMC and VT are transitional between those north of the Raymond fault and those in the Los Angeles Basin. The apparent minimum response at VT for waves having periods of slightly less than 1 sec. may result from accumulation of accidental errors. Out of nine observations with $0.6 \leqq T \leqq 1.1$ sec., six give ratios between $1 \frac{3}{4}$ and $23 / 4$. 
Observations on crystalline rock (fig. 20, c) show relatively small differences which may at least partly result from structural complications (WHS, fig. 7) or topography (MtW, Gutenberg, 1956b).

Periods for which the ground response shows a maximum relative to that at SL are plotted in figure $22, b$ as function of the thickness of the alluvium.

The foregoing results show that in refined determination of earthquake magnitudes from body waves, recorded at sites on sediments, station corrections should be used which depend on the periods of the waves.

SL

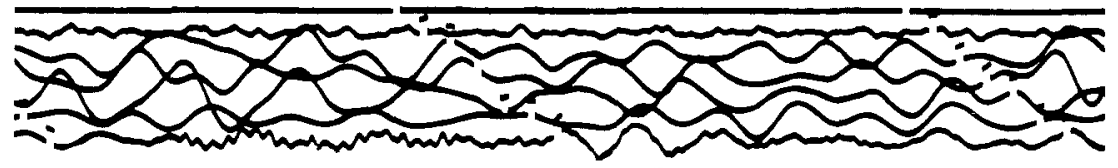

RN

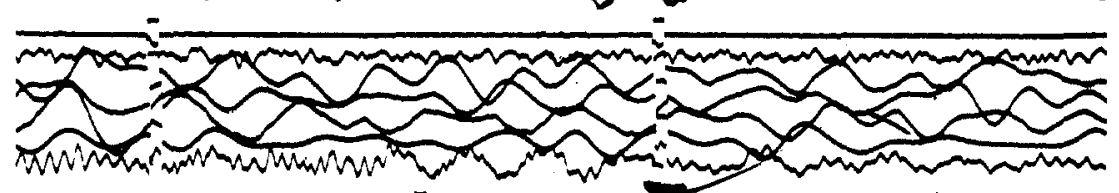

VT

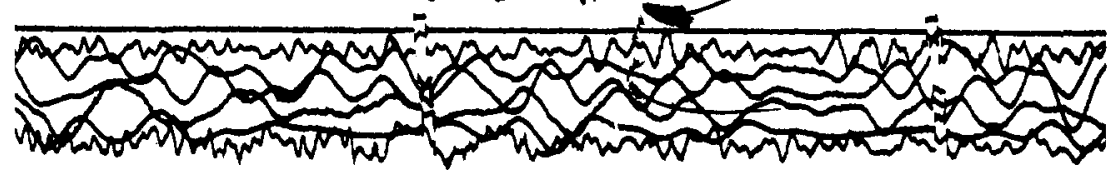

HPC
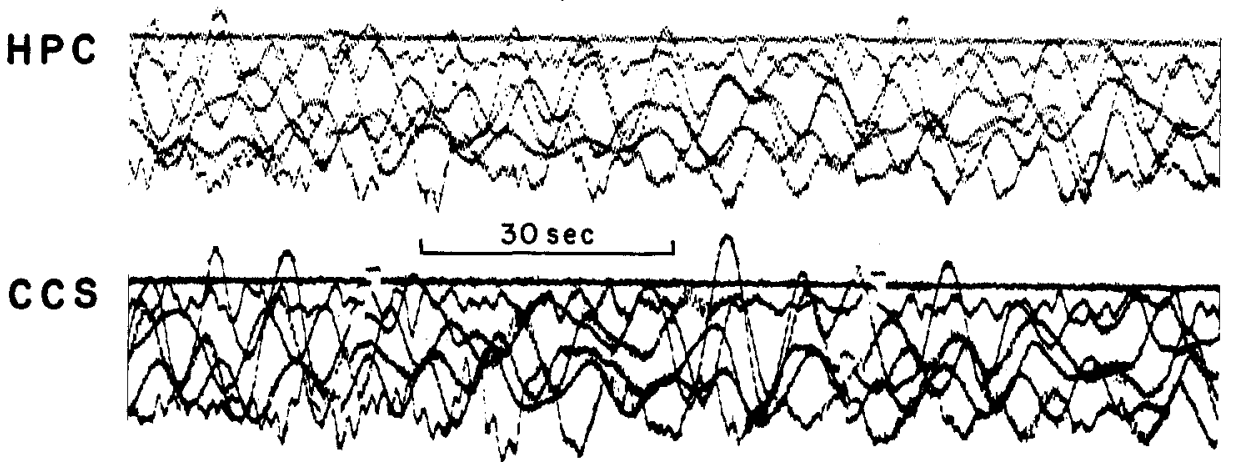

Fig. 21. Seismograms of portion of main Aleutian shock, March 9, 1957, and beginning of aftershock, $1^{\mathrm{h}} 20^{\mathrm{m}} \pm$ later. On SL record, successive lines are shifted to right relative to other records.

\section{Effects of Ground on Amplitude Maxima on Seismograms}

An increase of the maximum amplitude in near-by earthquakes with increasing thickness of the alluvium has been observed repeatedly (see, e.g., Omote, Komaki, and Kobayashi, 1956, p. 355). Figure 22, $c$ shows that in areas near Pasadena (ground-water level below about 200 feet), at a site with a thickness $D \leqq 1 / 2 \mathrm{~km}$. (or $d \leqq 1,500$ feet), the ratio of the maximum displacement in waves having periods of $1 / 2$ to $1 \frac{1}{2}$ sec. to the maximum displacement at SL is given roughly by

$$
m=1+11 D \quad \text { or } \quad m=1+d / 300
$$

For CCS and HPC, equation (1) gives too great values for $m$. However, for both, all individual values of $m$ are greater than 1 , if $T<20$ sec. Twelve values of $m$ 

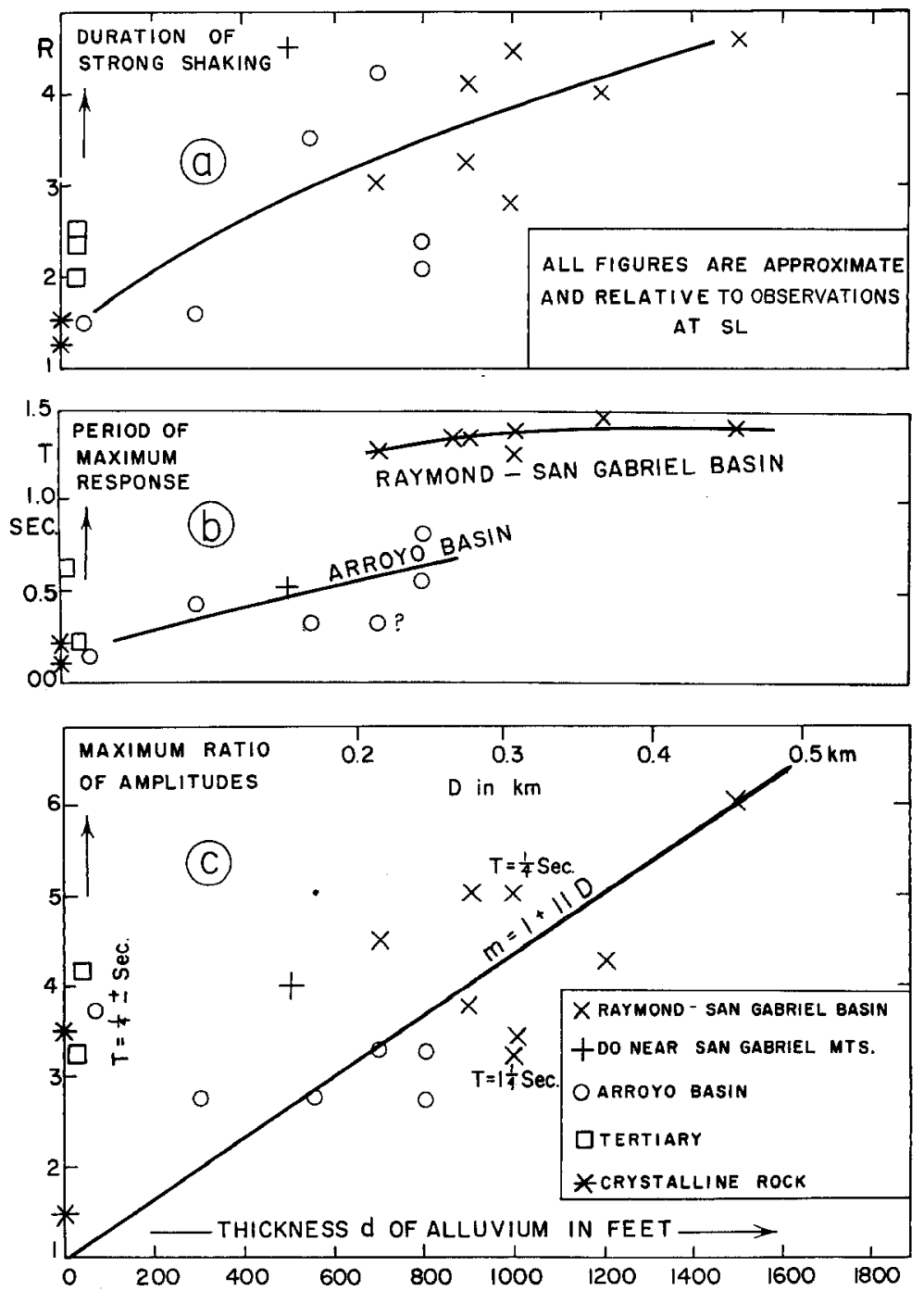

Fig. 22. $a$, Average ratio of duration of relatively strong shaking to that at SL. $b$, Periods for which ground shows maximum response. $c$, Average ratio of maximum amplitudes to those at SL; as function of thickness of alluvium.

recorded at CCS in short-period waves $\left(T<0.6\right.$ sec.) scatter between $1 \frac{1}{2}$ and 16 ; four out of twelve observations for $m$ in the period range between 3 and 9 sec. at HPC are over 6.

Relatively large amplitudes of waves having periods of roughly $1 / 4$ sec. may be observed in areas with only a thin layer of alluvium covering crystalline rock and may at least partly result from resonance effects (NM?), topography, or accumulation of water in the ground (SRS?). These sites show usually relative small response if $T>1$ sec. 


\section{Variations in Shaking of the Ground Affected by Buildings}

Research by earthquake engineers has left no doubt that the amount of shaking changes (frequently increases) with the height inside a building. For this reason, in the present investigation all instruments have been placed on a ground floor or in a basement. To assist investigation of effects of depth of installation and of the type of building, since March 15, 1957, the instruments have been operating simultaneously at various locations at SL. There are now two buildings, the Kresge Laboratory at 220 North San Rafael Avenue, where instrument II is recording on a pier in the basement, and the new Donnelley Laboratory about 600 feet farther west at 295 North San Rafael Avenue.

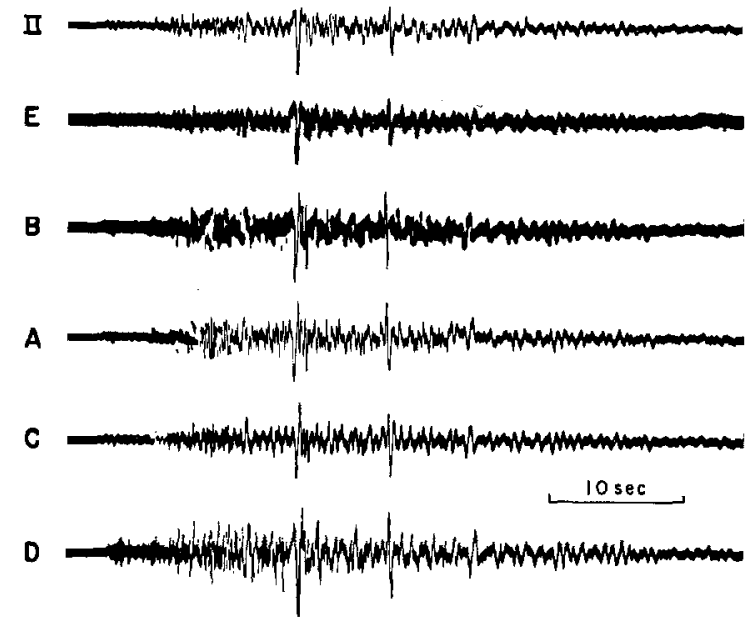

Fig. 23. Seismograms" of shock of March 18, 1957, 2 A.M., P.S.T., near long Beach, $\Delta=45 \mathrm{~km}$., $M=3 \pm$, recorded by instrument II in SL instrument room; $E$ on floor of SL garage; $A$ to $C$ in SL Donnelley building ( $B$ in furnace room, $A$ in garage, both on ground floor; $C$ in tunnel through granite); $\mathrm{D}$ in garden house; maximum distance between instruments less than 1,000 feet, details in text. Note possible effects of instruments on waves having periods $T<0.2$ sec.

Between March 15 and 19, instrument E recorded in the garage about 100 feet west of the Kresge Laboratory, instrument $B$ in the furnace room (ground floor), and $\mathrm{A}$ in the garage in the 3-story concrete Donnelley building (until March 25), $\mathrm{C}$ in an $\mathrm{E}-\mathrm{W}$ tunnel 150 feet long about 60 feet below the ground floor, and $\mathrm{D}$ on flagstones on soil in a lightly built garden house (barbecue) in a little valley about 200 feet southwest of the tunnel. The records include several large aftershocks of the great Aleutian earthquake of March 9. Figure 23 gives examples of records, and table 3 shows selected amplitude ratios for this period. Although some deviations of ratios from 1.0 result from the limits of accuracy in measuring trace amplitudes, others eorrespond to actual differences in ground motion at these sites less than 1,000 feet apart. The relatively large amplitudes, especially of short-period motion, recorded in the garden house may be affected by the foundation of $D$, which was less firm than any used in the main experiments, but the ground plays probably the main role. Neither the original test (fig. 3), nor a special test of tilt sensitivity on 
March 19, nor the final tests at SL, indicate any unusual behavior of D. Records at other locations near SL (fig. 23, table 3) show smaller differences.

Instruments D and E recorded in the garden house from March 19 to 25, B and C in the tunnel from March 19 to 28. From March 25 to 28, D recorded in the Kresge building on a pier anchored at a depth of several feet in the granitic rock, $\mathrm{E}$ next to $\mathrm{D}$ on the concrete floor resting on weathered granite. On March 28, D and $\mathrm{E}$

TABLE 3

Selected Ratios of Trace Amplitudes (EW) Recorded within 800 Feet of Instrument II by Instruments A to E to Those Recorded Simultaneously BY Routine Instrument II AT SL

(For locations of instruments, see text. Note that locations of instruments $B$ and E were changed and that $\mathrm{D}$ was tested on March 19.)

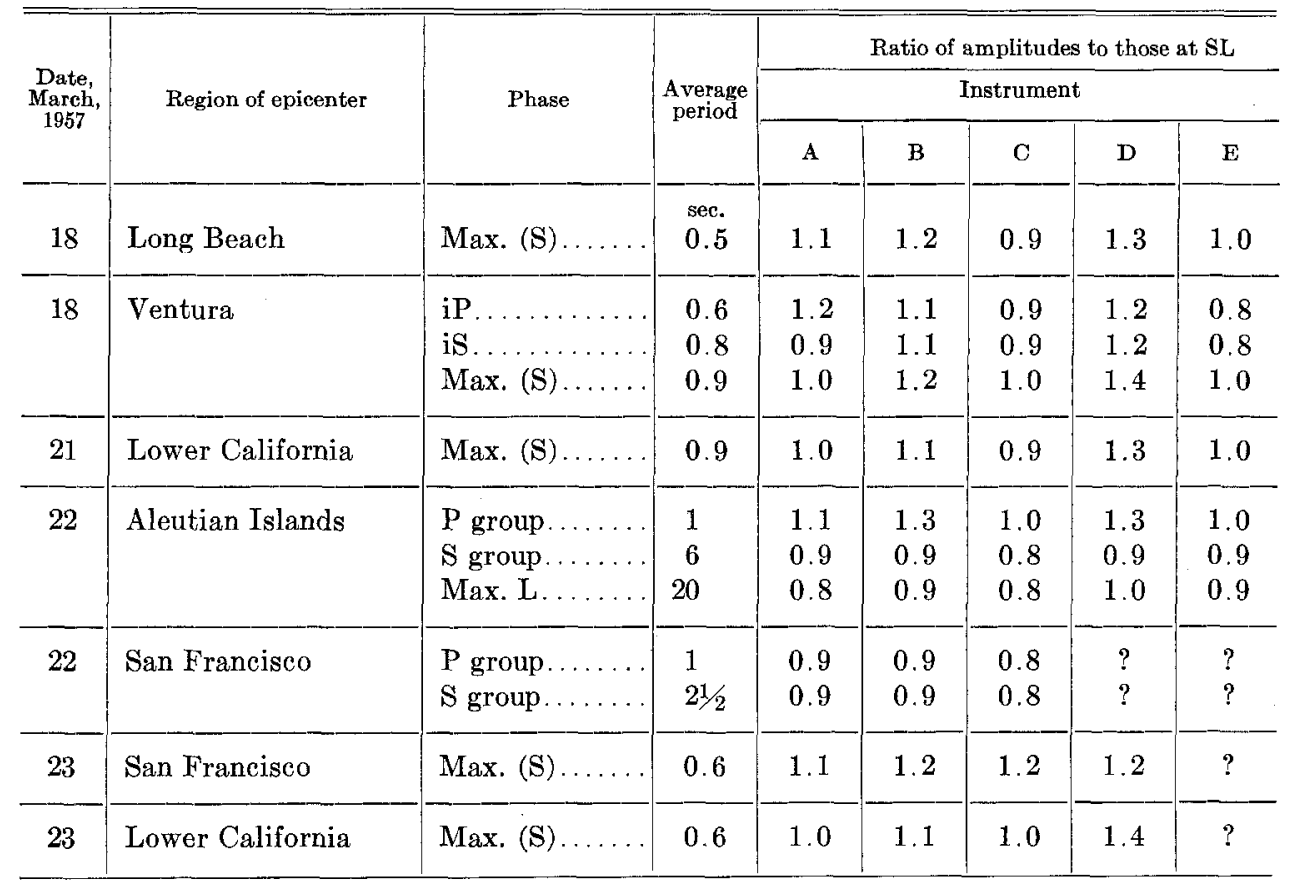

were exchanged. Most records written by D or E on the pier agree within expectable limits with those written by II on a similar pier and with those written by $\mathrm{B}$ and $\mathrm{C}$ in the tunnel through granitic rock. Waves recorded by the instrument on the floor show occasionally deviations of amplitudes from those recorded by instruments on piers by as much as 30 per cent. However, all differences found near SL between March 15 and April 3, 1957, are negligible as compared with those found on different ground before March 15 (compare fig. 23 with figs. 10-12, 15, 16).

\section{Theoretical Considerations}

Theoretical treatment of problems related to effects of the ground on shaking in earthquakes is difficult, since the surface layers are neither homogeneous nor 
bounded by planes. Jacobsen (1930) finds that under idealized conditions in a damped medium frequency-amplitude curves may be expected which in the ranges of "resonance" are similar to the magnification curves for a damped pendulum. Most curves of figure 20 have such forms. Effects of "soft" surface layers on waves having lengths much greater than the thickness of these layers should be small.

Kanai, Takahashi, and Kawasumi (1956, p. 11) conclude similarly from mathematical and observational study of earthquake motion by various authors that "the ground with a surface layer has spectral response of the resonance-curve type." Omote, Komaki, and Kobayashi (1956, p. 360) have used equations of Kanai to calculate amplitudes of waves having various periods. They find it "difficult to prove theoretically that waves with the periods assumed [by them] exist as stationary waves in surface layers."

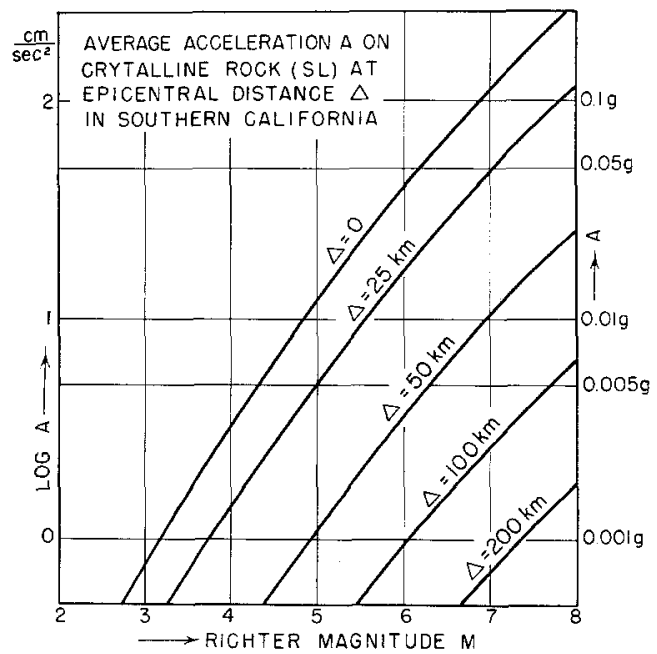

Fig. 24. Average acceleration on crystalline rock in southern California earthquakes as function of epicentral distance $\Delta$ and earthquake magnitude $M$, based on Gutenberg-Richter (1956).

In free vibrations (period $T$ ) of a homogeneous surface layer (thickness $D$, velocity $V), D=n V T ; n=$ number of waves. $T$ in seconds should be of the same order of magnitude as $D$ in $\mathrm{km}$. Figure 22, $b$ indicates that near Pasadena roughly $T=3 D$.

\section{CONCLUSIONS}

In a discussion of potential effects of earthquakes on structures, findings of the present investigation and results concerning effects of local geology on wave propagation should be combined with results reported by engineers concerning vibrations of structures. It follows, for example, from the present investigation that, generally, shaking is relatively strong where the ground-water table is close to the surface. In addition, in the epicentral area of minor shocks prevailing periods of about $1 / 4 \mathrm{sec}$. or less may be expected to produce relatively heavy shaking at sites where thin alluvium covers solid rock. As the magnitude of the shocks increases, periods of $1 / 2$ to $3 / 4$ sec. play a greater role, and sites on thick alluvium must be expected to under- 
go relatively heavy shaking. Since ratios between the amplitudes on alluvium to those on rock may be as great as 10 or more, the resulting acceleration may show a similar ratio between a site on "poor" ground and one on crystalline rock. Figure 24 indicates that even in a major earthquake the acceleration on crystalline rock usually remains well below $g$, but that it may exceed $g$ on "poor" ground.

Relatively long-lasting shaking may be expected in areas with thick alluvial cover; on water-saturated ground, waves having periods of a fraction of a second produce prolonged shaking. Near the coast, areas with thick alluvium and shallow water table show such large short-period continuous unrest that only low-magnification instruments can be used for investigation of ground effects on shaking in earthquakes. In general, appreciable differences in shaking may exist at sites only a thousand feet apart.

The old conclusion still holds: that, for finding the safest location for a building in a region where there are active faults, it is more important to look for sites on bedrock than for locations with a maximum distance from the faults. This advice also allows for the fact that a fault considered to be dead may well become alive again and that frequently the location of faults is unknown.

\section{ACKNOWLEDGMENTS}

The present research would not have been possible without the coöperation of the various organizations and persons who volunteered to have a seismograph. installed in their buildings or have participated otherwise in the investigation. In addition to staff members and assistants of the Seismological Laboratory whose names are marked by asterisks in the list of stations, there are included: the Pasadena City Board of Education; Dr. S. F. McComb, Superintendent of the Schools; Mr. William Krantz, Superintendent of Maintenance, Pasadena City Schools; the principals of the schools listed; Dr. J. E. Pomfret, Director of the Huntington Library; Mr. F. B. Runyon, Editor-in-Chief of the Pasadena Star-News; Mr. C. E. Martin, City Manager, San Marino; Mr. Erickson, Business Manager, and Mr. J. H. Park, Consulting Engineer, Compton City Schools; Mr. Stevens, City Manager, Mr. D. W. Mansfield, Assistant City Manager, and Mr. Patrick, City Engineer, Torrance; Dr. N. D. Myers, Superintendent, Palos Verdes School District; Mr. H. E. Robinson, City Engineer, Huntington Park; Mr. R. Griffith, of Lehner and Griffith, Altadena; Mrs. E. Frackelton; all those who faithfully have changed records, including Dr. Markus Båth; Mr. F. Lehner and his aides, who have installed and supervised all assemblies; Miss G. Killeen, who has unfailingly developed and finished the approximately thousand records; Mr. J. M. Nordquist, who has arranged and drafted most of the figures; the Los Angeles Office of the State of California Department of Water Resources and the Pasadena Water Department, for information on the ground-water table; Drs. Allen, Benioff, Press, and Richter, for discussions and suggestions; and the Donors for Earthquake Research at the Seismological Laboratory, whose financial support was used for part of the research. 


\section{REFERENCES}

Anderson, J. A., and H. O. Woop

1925. "Description and Theory of the Torsion Seismometer," Bull. Seism. Soc. Am., 15: 1-72.

BUWALDA, J. P.

1948. "Geologic Faulting in Southern California," Engineering and Science, Calif. Inst. Technol. February, pp. 15-18.

EckIs, R.

1934. "Geology and Ground-Water Storage Capacity of Valley Fill," South Coastal Basin Investigation, Calif. Div. of Water Resources, Bull. No. 45, 279 pages, 24 pl., 5 maps.

GUTENBERG, B.

1927. Grundlagen der Erdbebenkunde (Berlin).

1936. "Periods of the Ground in Southern California Earthquakes," Earthquake Investigations in California 1934-1935, U. S. Coast and Geodetic Survey Spec. Publ. 201, pp. 163-225.

1951. "Revised Travel Times in Southern California," Bull. Seism. Soc. Am., 41: 143-163.

1956a. "Effects of Ground on Shaking in Earthquakes," Trans. Am. Geophys. Union, 37: 757760.

1956b. "Comparison of Seismograms Recorded on Mount Wilson and at the Seismological Laboratory, Pasadena," Ann. de Géophys., 12: 202-208.

Gutenbere, B., and John P. Buwalda

1935. "Seismic Profile across the Los Angeles Basin," paper presented at the Cordilleran Section, Geol. Soc. Am.

GutenberG, B., and C. F. Richter

1956. "Earthquake Magnitude, Intensity, Energy, and Acceleration," Bull. Seism. Soc. Am., 46: $105-145$.

JACOBSEN, L. S.

1930. "Motion of a Soil Subjected to Simple Harmonic Ground Vibration," an approximate solution of the steady forced vibration ... (followed by discussions by A. L. Kimball and by E. O. Waters), Bull. Seism. Soc. Am., 20: 160-230.

JAHNS, R., ed.

1954. "Geology of Southern California," Calif. Div. of Mines, Bull. 170, 15 parts, incl. many maps and 34 map sheets.

Kanai, K., R. Takahashi, and H. KaWasumi

1956. "Seismic Characteristics of Ground," Proc. World Conference on Engineering, Earthq. Eng. Res. Inst., No. 31, pp. 1-16.

MALLET, $R$.

1862. Great Neapolitan Earthquake of 1857 (2 vols.; London).

MrLNe, J.

1908. Seismology (2d ed.; London).

NeUMaNn, F.

1954. Earthquake Intensity and Related Ground Motion (Univ. of Washington Press).

OMOTE, S., S. KoMaKI, and N. KoBaYashi

1956. "Earthquake Observations ... and the Seismic Qualities of the Ground," Bull. Earthq. Res. Inst. Tokyo, 34: 335-364.

REID, H. F.

1910. "The California Earthquake of April 18, 1906," Vol. 2: The Mechanics of the Earthquake, Carnegie Inst. of Washington, Publ. 87.

RICHTER, C. F.

1948. "History and Application of the Magnitude Scale," Bur. Centr. Seismol. Internat. Trav. Scientif., Fasc. 17, pp. 217-224.

Steberg, A.

1904. Handbuch der Erdbebenkunde (Braunschweig). 
SKLAR, M.

1955. "Application of Seismic Methods to Petroleum Exploration in the San Joaquin Valley," Earthquakes in Kern County, California, during 1952, Calif. Div. of Mines, San Francisco, Bull. 171.

UHRIG, L. F., and S. SCHAFER

1937. "Observed and Calculated Values of the Magnetic Intensity over a Major Geologic Structure," Gerlands Beitr. z. Geophysik, 49: 129-139.

Califormia Institute of Technology, Pasadena, California.

(Division of the Geological Sciences, contribution no. 831.) 